Article

\title{
Composition and Antioxidant, Antienzymatic and Antimicrobial Activities of Volatile Molecules from Spanish Salvia lavandulifolia (Vahl) Essential Oils
}

\author{
Ana-Belen Cutillas ${ }^{1, *}$ (D) , Alejandro Carrasco ${ }^{1}$ (D), Ramiro Martinez-Gutierrez ${ }^{2}$, Virginia Tomas ${ }^{3}$ \\ and Jose Tudela ${ }^{1}$ \\ 1 GENZ—Group of Research on Enzymology, Department of Biochemistry and Molecular Biology-A, \\ Regional Campus of International Excellence "Campus Mare Nostrum", University of Murcia, 30100 Murcia, \\ Spain; alejandro.carrasco@um.es (A.C.); tudelaj@um.es (J.T.) \\ 2 Novozymes Spain S.A., 28224 Madrid, Spain; rma@novozymes.com \\ 3 Department of Analytical Chemistry, University of Murcia, 30100 Murcia, Spain; virginia@um.es \\ * Correspondence: anabelen.cutillas@um.es; Tel./Fax: +34-8688-8478-2
}

Received: 21 June 2017; Accepted: 18 August 2017; Published: 21 August 2017

\begin{abstract}
The current study describes the composition of Salvia lavandulifolia (Vahl) essential oils (SIEOs) obtained from plants cultivated in Murcia (Spain), as determined by gas chromatography. Relative and absolute concentrations, the enantiomeric ratios of chiral compounds and the in vitro antioxidant, antienzymatic and antimicrobial activities are described. The main components of the SlEOs were camphor, 1,8-cineole, camphene and $\alpha$-pinene, and the main enantiomers were $(+)$-camphor and (-)-camphene. The activities against free radicals and the capacity to reduce and chelate metallic ions were measured. SIEO-3 showed the highest activity in ORAC, DPPH, ABTS and reducing power methods, while SIEO- 1 exhibited the highest chelating power. The activity of lipoxygenase and acetylcholinesterase could be inhibited by all the SIEOs, being bornyl acetate and limonene the most active individual compounds against lipoxygenase and 1,8-cineole against acetylcholinesterase. SIEOs and some individual compounds inhibited Escherichia coli, Staphylococcus aureus and Candida albicans. These results increase our knowledge of SIEOs and, particularly, provide for the first time a complete characterization of SIEOs from Murcia, Spain, while proposing possible biotechnological uses for them.
\end{abstract}

Keywords: Salvia lavandulifolia; essential oil; GC-FID; GC-MS; antioxidant capacity; enzymatic inhibition; antimicrobial activity

\section{Introduction}

Salvia, the largest genus of the Lamiaceae family, comprises nearly 900 species distributed throughout the world. Some species of Salvia have been cultivated for their use in folk medicine and for culinary purposes. Salvia lavandulifolia Vahl. (Salvia officinalis subsp. lavandulifolia (Vahl) Gams or Spanish sage) is native to the Iberian Peninsula and grows from south-east of Morocco to the Mediterranean area of France. It is a small woody herbaceous perennial shrub, ranging from 17 to $100 \mathrm{~cm}$ high, with mauve-blue flowers that usually grows on the sandy-calcareous soils of mountainous areas (from 300 to more than $1000 \mathrm{~m}$ above sea level) [1].

The essential oil (EO) composition of the genus Salvia is highly variable, depending on climatic, geographical and seasonal conditions as well as genotypic factors [2-5]. S. lavandulifolia EO (SIEO) has been described as a safe memory enhancer, suggesting it could be used in Alzheimer's disease therapy [6-9]. Moreover, SIEO presents other notable activities with medical applications, which include spasmolitic [10], oestrogenic [11] and antimicrobial [12] properties. 
The most common technique used for the analysis of volatile components is gas chromatography coupled with a flame ionization detector (GC-FID) or with a mass spectrometry detector (GC-MS), because these methods provide qualitative and quantitative data, even for complex mixtures, with high sensitivity and resolution. Some studies have reported the relative quantitation of SlEO from other Spanish regions [1,7,13-16] and from other countries (Poland [17], Germany [12] and Brazil [18,19]). None of them have studied SIEOs from Murcia nor made a chiral characterization of the EOs from this species. The chiral distribution of the principal compounds, as an essential part of quality assurance, helps to determine the genuineness or adulteration of EOs [20]. Besides, the enantiomeric ratio of a compound can cause significant differences from the point of view of sensorial analysis and bioactivity [21,22].

Reactive oxygen species (superoxide radical, hydrogen peroxide, etc.) have been implicated in the pathology of several human diseases (cancer, atherosclerosis, malaria, rheumatoid arthritis and neurodegenerative diseases, and aging effects [23-27]), and in the deterioration of food and cosmetic products [28]. The use of EOs as natural antioxidant is regarded as a safe alternative to synthetic ones $[29,30]$.

Lipoxygenase enzyme (LOX) produces hydroperoxyeicosatetraenoic acids (HPETEs) and hydroxyoctadecadienoic acids (HODEs) from arachidonic acid and linoleic acid, respectively [31]. SIEO can be useful to inhibit this enzyme and, therefore, may represent a valid strategy for prevention and therapy of Alzheimer's, cancer and inflammatory diseases [32]. As well as this bioactivity, SlEO shows acetylcholinesterase (AChE) inhibitory activity $[6,9,11,33]$, so it can be used as memory enhancer in Alzheimer's disease [34,35].

Some studies from other regions or countries reported the antibacterial and antifungal activities of EOs from Salvia genus [19,36-38]. These activities are highly related with the particular EO composition and microbial strain used in the assays. The antimicrobial capacity of EOs lends weight to their use as natural preservatives.

In this study, we describe the detailed volatile compositions of four SIEOs from the province of Murcia (Spain) and evaluate whether they fulfill the requirements of ISO 3526 [39]. The enantiomeric ratios of the commercially available compounds are also reported. The in vitro antioxidant and antimicrobial activities of these SIEOs are studied to ascertain their potential use as natural preservatives. The inhibition of LOX and AChE by SIEOs could lead to useful strategies for the treatment of inflammatory and Alzheimer's diseases and for natural insecticidal purposes.

\section{Results and Discussion}

\subsection{Fast Gas Chromatography (FGC-FID and FGC-MS) Study}

\subsubsection{Experimental Data}

The obtained yields for all the SIEOs ranged from $0.8 \%$ to $1.2 \%(v / w)$. The identified volatile components in the four SIEOs are summarized in Table 1, where $>99 \%$ of the total was identified, and $>93 \%$ of the total area is also expressed in absolute concentration. All four SlEOs under study contain camphor (30.8-37.2\%), 1,8-cineole (21.7-25.7\%), camphene (7.2-9.4\%) and $\alpha$-pinene (4.8-5.5\%) as main constituents. $\beta$-Pinene (4.0-5.6\%), limonene (2.8-4.4\%), myrcene (1.3-1.6\%) and sabinene $(1.3-1.8 \%)$ had significant concentrations in all the SlEOs.

To our knowledge, none of the previous studies have calculated the absolute amount of the volatile compounds. A higher percentage does not always mean a larger concentration; for instance, in this study, SIEO-1 has a higher percentage of 1,8-cineole than SIEO-3, but the concentration in the first is lower. Moreover, this characterization is useful to detect $\mathrm{EO}$ adulterations with organic solvents.

Principal component analysis (PCA) was carried out with the relative compositions of the SlEOs and determined three principal components (Figure 1A,B): PC1 (77.51\% of the total variance), PC2 (12.41\% of the total variance) and PC3 (10.09\% of the total variance). SIEO-1, -2 and -4 have similar values for PC1, which contributes to the highest percentage of the total variance. 
Table 1. Fast gas chromatography determination of SIEO compounds.

\begin{tabular}{|c|c|c|c|c|c|c|c|c|c|c|c|c|c|}
\hline \multirow{3}{*}{$\mathrm{N}^{\mathrm{a}}$} & \multirow{3}{*}{ LRI $^{b}$} & \multirow{3}{*}{ LRI $^{\mathrm{c}}$} & \multirow{3}{*}{ Compound } & \multirow{3}{*}{$\begin{array}{l}\text { Qualifying and } \\
\text { Quantitation } \\
\text { Ions }{ }^{d}(m / z)\end{array}$} & \multicolumn{2}{|l|}{ SIEO-1 } & \multicolumn{2}{|l|}{ SIEO-2 } & \multicolumn{2}{|l|}{ SIEO-3 } & \multicolumn{2}{|l|}{ SIEO-4 } & \multirow{2}{*}{ IM } \\
\hline & & & & & Concentration & Area & Concentration & Area & Concentration & Area & Concentration & Area & \\
\hline & & & & & $(\mathrm{mmol} / \mathrm{L} \pm \mathrm{SD})$ & $(\% \pm S D)$ & $(\mathrm{mmol} / \mathrm{L} \pm \mathrm{SD})$ & $(\% \pm S D)$ & $(\mathrm{mmol} / \mathrm{L} \pm \mathrm{SD})$ & $(\% \pm S D)$ & $(\mathrm{mmol} / \mathrm{L} \pm \mathrm{SD})$ & $(\% \pm \mathrm{SD})$ & \\
\hline 1 & 922 & 923 & Tricyclene & $79,93,121,136$ & & $0.1 \mathrm{f} \pm 0$ & & $0.1 \mathrm{~g} \pm 0$ & & & & $0.1 \mathrm{e} \pm 0$ & 1,2 \\
\hline 2 & 928 & 926 & $\alpha$-Thujene & $77,91,93,136$ & & $0.5 \mathrm{f} \pm 0$ & & $0.4 \mathrm{f} \pm 0$ & & $0.6 \mathrm{e} \pm 0$ & & $0.5 f \pm 0.1$ & 1,2 \\
\hline 3 & 930 & 936 & $\alpha$-Pinene & $77,91,93,121$ & $347.0 \mathrm{~b} \pm 7.6$ & $5.5 \mathrm{e} \pm 0$ & $297.2 \mathrm{c} \pm 3.4$ & $4.8 \mathrm{~g} \pm 0$ & $382.8 \mathrm{a} \pm 9.3$ & $5.3 \mathrm{f} \pm 0$ & $322.7 b c \pm 15.4$ & $4.9 \mathrm{~g} \pm 0$ & $1,2,3$ \\
\hline 4 & 943 & 953 & Camphene & $79,93,121,136$ & $582.1 \mathrm{~b} \pm 9.9$ & $8.1 \mathrm{f} \pm 0$ & $491.0 \mathrm{c} \pm 3.3$ & $7.2 \mathrm{~h} \pm 0$ & $759.3 a \pm 21.1$ & $9.4 \mathrm{e} \pm 0$ & $559.2 \mathrm{~b} \pm 42.4$ & $7.5 \mathrm{~g} \pm 0$ & $1,2,3$ \\
\hline 5 & 964 & 974 & Sabinene & $77,91,93,136$ & $100.0 \mathrm{c} \pm 1.7$ & $1.4 \mathrm{f} \pm 0$ & $105.0 \mathrm{~b} \pm 0.9$ & $1.4 \mathrm{f} \pm 0$ & $130.4 a \pm 1.1$ & $1.8 \mathrm{e} \pm 0$ & $92.6 \mathrm{~d} \pm 2$ & $1.3 g \pm 0$ & $1,2,3$ \\
\hline 6 & 970 & 982 & $\beta$-Pinene & $69,79,91,93$ & $267.7 \mathrm{c} \pm 2.8$ & $4.3 \mathrm{f} \pm 0$ & $281.4 b \pm 2.3$ & 4.3. $\mathrm{f} \pm 0$ & $416.4 \mathrm{a} \pm 2.8$ & $5.6 \mathrm{e} \pm 0$ & $249.1 \mathrm{~d} \pm 3.8$ & $4.0 \mathrm{~g} \pm 0$ & $1,2,3$ \\
\hline 7 & 979 & 989 & Myrcene & $41,69,93,121$ & $115.0 \mathrm{c} \pm 1.2$ & $1.3 \mathrm{~g} \pm 0$ & $120.6 \mathrm{~b} \pm 1$ & $1.4 \mathrm{f} \pm 0$ & $135.5 a \pm 0.6$ & $1.6 \mathrm{e} \pm 0$ & $104.4 \mathrm{~d} \pm 2.5$ & $1.3 \mathrm{f} \pm 0$ & $1,2,3$ \\
\hline 8 & 999 & 1008 & $\alpha$-Phellandrene & $77,93,119,136$ & $2.7 \mathrm{a} \pm 0.1$ & $\operatorname{tr}$ & $1.7 \mathrm{c} \pm 0$ & $\operatorname{tr}$ & $2.0 \mathrm{~b} \pm 0.2$ & $\operatorname{tr}$ & & & $1,2,3$ \\
\hline 9 & 1008 & 1017 & $\alpha$-Terpinene & $91,93,119,121$ & $5.6 a \pm 0.2$ & $0.1 \pm 0$ & $3.4 \mathrm{~b} \pm 0$ & $\operatorname{tr}$ & $3.1 \mathrm{c} \pm 0.1$ & tr & $2.8 c \pm 0.1$ & $\operatorname{tr}$ & $1,2,3$ \\
\hline 10 & 1011 & 1024 & p-Cymene & $91,117, \mathbf{1 1 9}, 121$ & $31.4 b \pm 0.3$ & $0.8 \mathrm{e} \pm 0$ & $32.0 \mathrm{~b} \pm 0.4$ & $0.7 \mathrm{~g} \pm 0$ & $28.5 c \pm 0.2$ & $0.6 \mathrm{~h} \pm 0$ & $33.3 a \pm 0.7$ & $0.7 \mathrm{f} \pm 0$ & $1,2,3$ \\
\hline 11 & 1020 & 1028 & Limonene & $67,68,79,93$ & $162.6 \mathrm{a} \pm 4.1$ & $4.4 \mathrm{e} \pm 0$ & $162.5 a \pm 1.6$ & $4.2 \mathrm{f} \pm 0$ & $106.7 \mathrm{c} \pm 1.4$ & $2.8 \mathrm{~h} \pm 0$ & $144.3 \mathrm{~b} \pm 2.6$ & $3.8 \mathrm{~g} \pm 0$ & $1,2,3$ \\
\hline 12 & 1023 & 1032 & 1,8-Cineole & $43,81,93,108$ & $1303.6 \mathrm{a} \pm 55.6$ & $24.2 \mathrm{~g} \pm 0.1$ & $1362.6 a \pm 35.2$ & $25.7 \mathrm{e} \pm 0.1$ & $1326.1 \mathrm{a} \pm 20.5$ & $21.7 \mathrm{~h} \pm 0.1$ & $1375.2 \mathrm{a} \pm 207.8$ & $24.7 f \pm 0.1$ & $1,2,3$ \\
\hline 13 & 1053 & 1055 & $\gamma$-Terpinene & $77,91,93,119$ & $14.3 \mathrm{a} \pm 0.5$ & $0.1 \mathrm{~h} \pm 0$ & $6.7 c \pm 0.1$ & $0.1 \mathrm{~g} \pm 0$ & $8.1 b \pm 0.4$ & $0.2 \mathrm{e} \pm 0$ & $5.8 c \pm 0.1$ & $0.1 \mathrm{f} \pm 0$ & $1,2,3$ \\
\hline 14 & 1070 & 1071 & Sabinene hydrate & $77,91,93,121$ & $14.9 \mathrm{c} \pm 0.6$ & $0.2 f \pm 0$ & $14.4 \mathrm{c} \pm 0.5$ & $0.2 \mathrm{f} \pm 0$ & $30.7 \mathrm{a} \pm 0.5$ & $0.4 \mathrm{e} \pm 0$ & $18.9 \mathrm{~b} \pm 0.7$ & $0.2 \mathrm{f} \pm 0$ & $1,2,3$ \\
\hline 15 & 1080 & 1086 & Terpinolene & $91,93,121,136$ & $10.8 a \pm 0.3$ & $0.2 \mathrm{~h} \pm 0$ & $7.9 b \pm 0.4$ & $0.2 \mathrm{~g} \pm 0$ & $11.2 \mathrm{a} \pm 0.3$ & $0.3 \mathrm{e} \pm 0$ & $6.5 c \pm 0.4$ & $0.2 \mathrm{f} \pm 0$ & $1,2,3$ \\
\hline 16 & 1081 & 1105 & Linalool & $41,67,69,93$ & $71.1 \mathrm{c} \pm 1.1$ & $1.3 \mathrm{~g} \pm 0$ & $97.7 \mathrm{a} \pm 2.1$ & $1.8 \mathrm{e} \pm 0$ & $10.0 \mathrm{~d} \pm 0.3$ & $0.2 \mathrm{~h} \pm 0$ & $90.0 \mathrm{~b} \pm 4$ & $1.7 \mathrm{f} \pm 0$ & $1,2,3$ \\
\hline 17 & 1143 & 1143 & cis-Sabinol & $81,91,92,134$ & & $2.2 \mathrm{e} \pm 0$ & & $1.5 \mathrm{~g} \pm 0.1$ & & $0.1 \mathrm{~h} \pm 0$ & & $2.1 \mathrm{f} \pm 0.1$ & 1,2 \\
\hline 18 & 1148 & 1147 & Camphor & $81,95,108,152$ & $1961.3 b \pm 121.6$ & $31.3 g \pm 0.2$ & $1715.1 \mathrm{~b} \pm 2.3$ & $30.8 \mathrm{~h} \pm 0$ & $2599.8 \mathrm{a} \pm 59.8$ & $37.2 \mathrm{e} \pm 0.1$ & $1899.0 \mathrm{~b} \pm 399.2$ & $31.5 f \pm 0.1$ & $1,2,3$ \\
\hline 19 & 1174 & 1173 & Borneol & $79,93,95,110$ & $166.1 b \pm 2.2$ & $2.8 \mathrm{~g} \pm 0$ & $171.7 \mathrm{~b} \pm 7.6$ & $2.9 \mathrm{f} \pm 0$ & $279.7 \mathrm{a} \pm 9.6$ & $4.3 \mathrm{e} \pm 0$ & $164.1 \mathrm{~b} \pm 4.6$ & $2.8 \mathrm{f} \pm 0$ & $1,2,3$ \\
\hline 20 & 1161 & 1180 & Terpinen-4-ol & $71,86,93,111$ & $35.8 \mathrm{a} \pm 1.7$ & $0.7 \mathrm{e} \pm 0$ & $32.6 \mathrm{ab} \pm 2.4$ & $0.6 \mathrm{f} \pm 0$ & $28.9 b \pm 2.2$ & $0.6 \mathrm{f} \pm 0$ & $37.0 \mathrm{a} \pm 2.3$ & $0.7 \mathrm{e} \pm 0$ & $1,2,3$ \\
\hline 21 & 1172 & 1190 & p-Cymen-8-ol & $43,91,135,150$ & & $0.1 \mathrm{f} \pm 0$ & & $0.1 \mathrm{f} \pm 0$ & & $0.1 \mathrm{~g} \pm 0$ & & $0.2 \mathrm{e} \pm 0$ & 1,2 \\
\hline 22 & 1192 & 1198 & $\alpha$-Terpineol & $59,67,93,121$ & $44.2 \mathrm{a} \pm 4.9$ & $0.5 \mathrm{~g} \pm 0$ & $43.3 a \pm 2.5$ & $0.6 \mathrm{f} \pm 0$ & $13.9 b \pm 0.7$ & $0.2 \mathrm{~h} \pm 0$ & $51.0 \mathrm{a} \pm 2.7$ & $0.6 \mathrm{e} \pm 0$ & $1,2,3$ \\
\hline 23 & 1191 & 1201 & (-)-Myrtenol & $79,91,93,119$ & & $0.1 \mathrm{f} \pm 0$ & & $0.1 \mathrm{f} \pm 0$ & $8.3 \pm 0.4$ & $0.1 \mathrm{e} \pm 0$ & & $0.1 \mathrm{e} \pm 0$ & $1,2,3$ \\
\hline 24 & 1223 & 1238 & (Z)-Citral & $79,91,119,134$ & & tr & & & & $0.1 \pm 0$ & & tr & 1,2 \\
\hline 25 & 1236 & 1249 & Linalyl acetate & $41,69,93,80$ & $123.5 c \pm 3.5$ & $1.5 \mathrm{~g} \pm 0$ & $175.8 \mathrm{a} \pm 1.9$ & $2.3 \mathrm{e} \pm 0$ & & & $149.8 \mathrm{~b} \pm 1.4$ & $2.1 \mathrm{f} \pm 0.1$ & $1,2,3$ \\
\hline 26 & 1232 & 1255 & Geraniol & $41,69,93,123$ & $27.7 \mathrm{a} \pm 1.1$ & $0.4 \mathrm{e} \pm 0$ & $24.5 a \pm 2.3$ & $0.4 \mathrm{e} \pm 0$ & $25.6 \mathrm{a} \pm 0.4$ & $0.4 \mathrm{e} \pm 0$ & $19.6 \mathrm{a} \pm 5.9$ & $0.4 \mathrm{e} \pm 0$ & $1,2,3$ \\
\hline 27 & 1285 & 1285 & Bornyl acetate & $79,93,95,121$ & $40.3 b \pm 1.1$ & $0.7 \mathrm{~g} \pm 0$ & $50.6 a \pm 0.9$ & $0.9 \mathrm{f} \pm 0$ & $50.7 \mathrm{a} \pm 1.5$ & $1.1 \mathrm{e} \pm 0$ & $39.0 \mathrm{~b} \pm 0.7$ & $0.7 \mathrm{~g} \pm 0.1$ & $1,2,3$ \\
\hline 28 & 1299 & 1290 & Sabinyl acetate & $81,92,119,134$ & & $3.2 \mathrm{e} \pm 0.1$ & & $3.0 \mathrm{f} \pm 0$ & & $\operatorname{tr}$ & & $2.9 \mathrm{f} \pm 0.1$ & 1,2 \\
\hline 29 & 1322 & 1344 & $\alpha$-Terpinyl acetate & $67,68,93,121$ & $60.9 \mathrm{~b} \pm 0.5$ & $1.2 \mathrm{f} \pm 0$ & $41.4 \mathrm{c} \pm 0.2$ & $0.8 \mathrm{~g} \pm 0$ & $4.4 \mathrm{~d} \pm 0.3$ & $0.1 \mathrm{~h} \pm 0$ & $74.4 a \pm 0.2$ & $1.6 \mathrm{e} \pm 0$ & $1,2,3$ \\
\hline 30 & 1360 & 1377 & Geranyl acetate & $41,67,69,93$ & $9.7 \mathrm{a} \pm 0.2$ & $0.4 \mathrm{e} \pm 0$ & $9.3 a \pm 0.3$ & $0.4 \mathrm{f} \pm 0$ & $8.6 \mathrm{~b} \pm 0.1$ & $0.2 \mathrm{~g} \pm 0$ & $9.1 \mathrm{ab} \pm 0.2$ & $0.5 \mathrm{e} \pm 0$ & $1,2,3$ \\
\hline 31 & 1412 & 1401 & $\alpha$-Gurjunene & $91,105,161,204$ & & $0.1 \mathrm{~g} \pm 0$ & & $0.1 \mathrm{f} \pm 0$ & & $0.1 \mathrm{e} \pm 0$ & & $0.1 \mathrm{~h} \pm 0$ & 1,2 \\
\hline 32 & 1421 & 1419 & $(E)-\beta$-Caryophyllene & $41,91,93,133$ & $54.7 \mathrm{c} \pm 0.9$ & $0.7 \mathrm{~g} \pm 0$ & $59.3 b \pm 1.7$ & $0.9 \mathrm{f} \pm 0$ & $144.7 \mathrm{a} \pm 0.5$ & $2.3 \mathrm{e} \pm 0$ & $43.6 \mathrm{~d} \pm 1.2$ & $0.7 \mathrm{~g} \pm 0$ & $1,2,3$ \\
\hline 33 & 1454 & 1459 & $\alpha$-Humulene & $80,93,107,204$ & $10.1 \mathrm{c} \pm 0.2$ & $0.3 \mathrm{~g} \pm 0$ & $11.9 \mathrm{~b} \pm 0.4$ & $0.3 \mathrm{f} \pm 0$ & $23.2 \mathrm{a} \pm 0.4$ & $0.8 \mathrm{e} \pm 0$ & $8.9 \mathrm{~d} \pm 0.1$ & $0.2 \mathrm{~g} \pm 0$ & $1,2,3$ \\
\hline 34 & 1454 & 1476 & Geranyl propionate & $41,69,93,120$ & & $0.4 \mathrm{f} \pm 0$ & & $0.5 \mathrm{e} \pm 0$ & & & & $0.4 \mathrm{f} \pm 0$ & 1,2 \\
\hline 35 & 1472 & 1482 & $\alpha$-Curcumene & $105,119,132,145$ & & $0.1 \mathrm{f} \pm 0$ & & $0.1 \mathrm{f} \pm 0$ & & $0.3 e \pm 0$ & & & 1,2 \\
\hline 36 & 1494 & 1496 & $\alpha$-Muurolene & $91,93,119,161$ & & $0.1 \mathrm{f} \pm 0$ & & $0.1 \mathrm{e} \pm 0$ & & $0.1 \mathrm{e} \pm 0$ & & $0.1 \mathrm{f} \pm 0$ & 1,2 \\
\hline 37 & 1507 & 1510 & $\gamma$-Cadinene & $91,105,119,161$ & & tr & & $0.1 \mathrm{f} \pm 0$ & & $0.1 \mathrm{e} \pm 0$ & & & 1,2 \\
\hline 38 & 1514 & 1517 & $\delta$-Cadinene & $91,119,134,161$ & & $0.1 \mathrm{fg} \pm 0$ & & $0.1 \mathrm{f} \pm 0$ & & $0.1 \mathrm{e} \pm 0$ & & $0.1 \mathrm{~g} \pm 0$ & 1,2 \\
\hline 39 & 1575 & 1579 & Caryophyllene oxide & $41,79,91,109$ & $8.9 b \pm 0.8$ & $0.3 \mathrm{f} \pm 0$ & $9.5 b \pm 0.3$ & $0.3 \mathrm{f} \pm 0$ & $17.2 \mathrm{a} \pm 2$ & $0.4 \mathrm{e} \pm 0$ & $10.3 b \pm 1.1$ & $0.3 \mathrm{f} \pm 0$ & $1,2,3$ \\
\hline 40 & 1594 & 1593 & Viridiflorol & $43,109,161,204$ & & $0.1 \mathrm{~h} \pm 0$ & & $0.1 \mathrm{e} \pm 0$ & & $0.1 \mathrm{f} \pm 0$ & & $0.1 \mathrm{~g} \pm 0$ & 1,2 \\
\hline
\end{tabular}


Table 1. Cont

\begin{tabular}{|c|c|c|c|c|c|c|c|c|c|c|c|c|}
\hline \multirow{3}{*}{$\mathrm{N}^{\mathrm{a}}$} & \multirow{3}{*}{ LRI $^{b}$} & \multirow{3}{*}{ Compound } & \multirow{3}{*}{$\begin{array}{l}\text { Qualifying and } \\
\text { Quantitation } \\
\text { Ions }^{\mathrm{d}}(\mathrm{m} / \mathrm{z})\end{array}$} & \multicolumn{2}{|l|}{ SIEO-1 } & \multicolumn{2}{|l|}{ SIEO-2 } & \multicolumn{2}{|l|}{ SIEO-3 } & \multicolumn{2}{|l|}{ SIEO-4 } & \multirow{3}{*}{ IM } \\
\hline & & & & Concentration & Area & Concentration & Area & Concentration & Area & Concentration & Area & \\
\hline & & & & $(\mathrm{mmol} / \mathrm{L} \pm \mathrm{SD})$ & $(\% \pm \mathrm{SD})$ & $(\mathrm{mmol} / \mathrm{L} \pm \mathrm{SD})$ & $(\% \pm \mathrm{SD})$ & $(\mathrm{mmol} / \mathrm{L} \pm \mathrm{SD})$ & $(\% \pm \mathrm{SD})$ & $(\mathrm{mmol} / \mathrm{L} \pm \mathrm{SD})$ & $(\% \pm \mathrm{SD})$ & \\
\hline \multicolumn{13}{|c|}{ Oxygenated terpenes: } \\
\hline \multicolumn{3}{|c|}{ Alcohol } & & & 8.3 & & 8.2 & & 6.5 & & 8.8 & \\
\hline \multicolumn{3}{|c|}{ Ketone } & & & 31.3 & & 30.8 & & 37.2 & & 31.5 & \\
\hline \multicolumn{3}{|c|}{ Aldehyde } & & & 0 & & 0 & & 0.1 & & 0 & \\
\hline \multicolumn{3}{|c|}{ Ester } & & & 7.5 & & 8 & & 1.4 & & 8.2 & \\
\hline \multicolumn{3}{|c|}{ Ether } & & & 24.5 & & 26.1 & & 22.1 & & 25 & \\
\hline \multicolumn{3}{|c|}{ Monoterpene hydrocarbons } & & & 26.7 & & 24.8 & & 28.2 & & 24.5 & \\
\hline \multicolumn{3}{|c|}{ Oxygenated monoterpenes } & & & 71.3 & & 72.7 & & 66.8 & & 73.2 & \\
\hline \multicolumn{3}{|c|}{ Sesquiterpene hydrocarbons } & & & 1.2 & & 1.7 & & 3.8 & & 1.2 & \\
\hline \multicolumn{3}{|c|}{ Oxygenated sesquiterpenes } & & & 0.4 & & 0.4 & & 0.5 & & 0.4 & \\
\hline \multirow{2}{*}{\multicolumn{3}{|c|}{ Total terpene hydrocarbons }} & & & 27.9 & & 26.5 & & 32 & & 25.7 & \\
\hline & & & & & 71.6 & & 73.1 & & 67.3 & & 73.6 & \\
\hline
\end{tabular}

${ }^{a}$ Reference number for statistical PCA graphs; ${ }^{\mathrm{b}}$ Linear Retention Index from data bases NIST 08 \& Wiley 7; ${ }^{\mathrm{c}}$ Linear Retention Index calculated from the homologous series of $n$-alkanes

(C7-C30); ${ }^{\mathrm{d}}$ Quantitation ions are shown in bold. a, b, c, d: different letters in the same compound concentration mean statistically significant differences with $p<0.05$. e, f, g, h: different letters in the same compound area mean statistically significant differences with $p<0.05$. IM, Identification method: $1=$ by LRI, $2=$ by NIST $08 \&$ Wiley $7,3=$ by comparison with pure compounds. tr, Traces $(<0.1 \%)$ 
Forty different compounds were described in the SIEOs (Figure S1). The loading plot (Figure 1B) allows us to establish relations between composition and the differences exhibited in the score plot. SlEO-1, -2 and -4 have similar concentrations of linalool (16), cis-sabinol (17), $\alpha$-terpineol (22), linalyl acetate (25), sabinyl acetate (28) and geranyl propionate (34), among others. However, SIEO-3 showed lower concentrations of the compounds detailed above, but higher concentrations of camphor (18), borneol (19), $\beta$-caryophyllene (32), $\alpha$-humulene (33) and $\alpha$-curcumene (35).
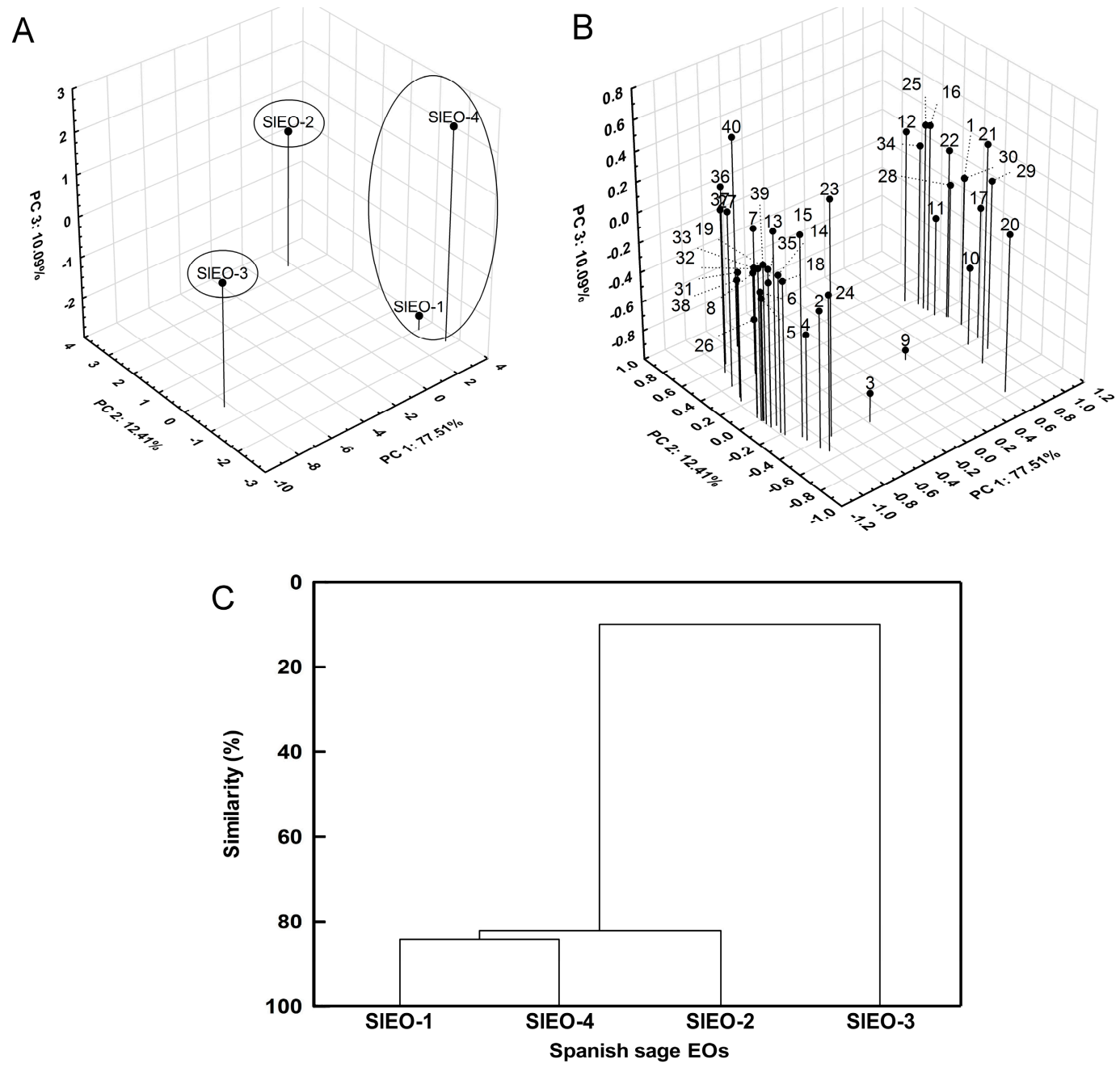

Figure 1. PCA and AHC analyses. (A) 3D-score plot of PC3 vs. PC2 and PC1; (B) 3D-loading plot of PC3 vs. PC2 and PC1; (C) AHC dendrogram: percentages of similarity between studied EOs and clusters.

Using the relative area of all compounds of the SIEOs (Table 1), the agglomerative hierarchical clustering (AHC) based on Euclidean distance was represented in a dendrogram (Figure 1C), showing that SIEO- 1 and -4 are the most similar with $84.2 \%$ similarity, followed by SIEO-2 with $82.3 \%$ similarity. This cluster of SIEOs reveals $9.8 \%$ of similarity with SIEO-3.

\subsubsection{Comparison with Previous Studies from Other Regions and Countries}

Other studies have reported the relative composition of SIEOs. Some differences existed in the main compounds; for example, while 1,8-cineole is present in our SIEOs with a maximum of $25.7 \%$, in other studies from Central Spain, this percentage reached 54.7\% of the total area [40]. Also, camphor showed high variability, ranging from $0 \%$ to $29 \%$ of the EO depending on the origin [1,7]. 
Most studies concerning the composition of SIEOs have been carried out in other regions of Spain. The EO composition depends on various external factors [13,14,16,40]. For example, 1,8-cineole and camphor were abundant components in almost all studies, while $\alpha$-pinene, $\beta$-pinene, limonene and linalool were considered the major components in fewer cases $[1,14,15]$. Our SlEOs from Murcia and those analyzed in other studies (except the one reported by Porres-Martinez et al. [13]) described the presence of $\beta$-myrcene in different percentages. This compound has been regarded as a chemotaxonomic marker of SIEO since it is relatively rare in other sage species [41]. Some SIEOs have high amounts of $\beta$-phellandrene [13] and spathulenol [1,40], whereas they are not present in others. These molecules can be used as markers of their respective growing areas.

Using the identified compounds (Table 1), oxygenated monoterpenes were clearly predominant (66.8-73.2\% of the total area) and oxygenated sesquiterpenes represented the lowest percentage $(0.4-0.5 \%$ of the total area). The most abundant organic functional group was ketone $(30.8-37.2 \%$ of the total area), followed by the ether group (22.1-26.1\% of the total area). This distribution is also found in other studies [13-15]. Herraiz-Penalver et al. [1] reported EO compositions of 20 SlEOs from the central region of Spain, which presented a higher percentage of monoterpenes than sesquiterpenes, with hydrocarbon monoterpenes as the major fraction.

The International Organization for Standardization (ISO) has published International Standards for SIEO [39]. Most of our results match the requirements of the ISO standard, although all the SIEOs showed a higher percentage of 1,8-cineole and camphor and SlEO-3 had a slightly lower amount of linalyl acetate, $\alpha$-terpinyl acetate and sabinyl acetate (Table 2). Some SIEOs from other regions of Spain fell below the requirements in the case of limonene [14], camphor [1,16], borneol [13] and sabinyl acetate [1,13,15,16] or exceeded the requirements for $\alpha$-pinene [1], 1,8-cineole [1,16], linalool [15], and borneol [7].

Table 2. SIEO compositions compared with ISO standard.

\begin{tabular}{|c|c|c|c|c|c|c|}
\hline Compound & \multicolumn{2}{|c|}{ ISO Standard $^{a}$} & S1EO-1 (\%) & SIEO-2 (\%) & S1EO-3 (\%) & S1EO-4 (\%) \\
\hline$\alpha$-Pinene & 4.0 & 11.0 & 7.0 & 6.2 & 7.2 & 6.2 \\
\hline Limonene & 2.0 & 6.0 & 5.7 & 5.3 & 3.8 & 4.9 \\
\hline 1,8-Cineole & 10.0 & 30.0 & 31.3 & 32.9 & 29.4 & 31.7 \\
\hline Borneol & 1.0 & 7.0 & 3.6 & 3.7 & 5.8 & 3.6 \\
\hline Terpinen-4-ol & - & 2.0 & 0.9 & 0.8 & 0.8 & 0.9 \\
\hline Linalyl acetate & 0.1 & 5.0 & 2.0 & 3.0 & 0.0 & 2.7 \\
\hline$\alpha$-Terpinyl acetate & 0.5 & 9.0 & 1.6 & 1.1 & 0.1 & 2.0 \\
\hline Sabinyl acetate & 0.5 & 9.0 & 4.1 & 3.8 & 0.0 & 3.7 \\
\hline
\end{tabular}

${ }^{a}$ ISO standard 3526 for Salvia lavandulifolia [39].

\subsection{Enantioselective Gas Chromatography-Mass Spectrometry (EsGC-MS) Study}

The enantiomeric ratios of commercially available components of SIEOs from Murcia have been obtained (Table 3). The (+)-enantiomer prevails in the case of limonene, sabinene hydrate, camphor, terpinen-4-ol, $\alpha$-terpineol and $\alpha$-terpinyl acetate, while the $(-)$-enantiomer predominates in camphene, $\beta$-pinene, linalool, bornyl acetate, borneol and $\beta$-caryophyllene. Linalool and $\alpha$-terpineol in SIEO-1 and limonene and terpinen-4-ol in SIEO-3 showed different distribution percentages compared with the other SIEOs. Different enantiomeric distributions of chiral compounds could provide diverse organoleptic properties, information about the origin, and also act as a tool to detect possible fraud in commercial EOs. To our knowledge, this study is the first one to present an extensive enantiomeric characterization of SIEO. 
Table 3. Enantiomeric ratios of SlEO compounds ${ }^{\text {a }}$.

\begin{tabular}{|c|c|c|c|c|c|c|c|c|c|c|}
\hline \multirow{2}{*}{\multicolumn{2}{|c|}{$t_{\mathrm{R}}(\min )$}} & \multirow{3}{*}{$\begin{array}{l}\text { Compound } \\
(X)\end{array}$} & \multicolumn{2}{|c|}{ SIEO-1 } & \multicolumn{2}{|c|}{ SIEO-2 } & \multicolumn{2}{|c|}{ S1EO-3 } & \multicolumn{2}{|c|}{ S1EO-4 } \\
\hline & & & $(+)-X$ & $(-)-X$ & $(+)-X$ & $(-)-X$ & $(+)-X$ & $(-)-X$ & $(+)-X$ & $(-)-X$ \\
\hline$(+)-X$ & $(-)-X$ & & $(\%)$ & $(\%)$ & $(\%)$ & $(\%)$ & $(\%)$ & $(\%)$ & $(\%)$ & $(\%)$ \\
\hline 7.79 & 7.52 & $\alpha$-Pinene & 52 & 48 & 53 & 47 & 46 & 54 & 53 & 47 \\
\hline 8.47 & 8.24 & Camphene & 26 & 74 & 27 & 73 & 32 & 68 & 39 & 61 \\
\hline 8.89 & 9.16 & $\beta$-Pinene & 42 & 58 & 41 & 59 & 27 & 73 & 39 & 61 \\
\hline 10.52 & 10.00 & Limonene & 81 & 19 & 86 & 14 & 63 & 37 & 87 & 13 \\
\hline 14.28 & 14.51 & Sabinene hydrate & $>95$ & $<5$ & $>95$ & $<5$ & $>95$ & $<5$ & $>95$ & $<5$ \\
\hline 15.73 & 15.57 & Linalool & 11 & 89 & 5 & 95 & $<5$ & $>95$ & 5 & 95 \\
\hline 16.72 & 16.46 & Camphor & 76 & 24 & 80 & 20 & 79 & 21 & 77 & 23 \\
\hline 18.02 & 18.18 & Bornyl acetate & $<5$ & $>95$ & $<5$ & $>95$ & $<5$ & $>95$ & $<5$ & $>95$ \\
\hline 18.32 & 18.51 & Terpinen-4-ol & 69 & 31 & 81 & 19 & 51 & 49 & 80 & 20 \\
\hline 20.10 & 19.76 & $\alpha$-Terpineol & 85 & 15 & $>95$ & $<5$ & $>95$ & $<5$ & $>95$ & $<5$ \\
\hline 20.15 & 19.58 & Borneol & 31 & 69 & 36 & 64 & 24 & 76 & 29 & 71 \\
\hline 20.91 & 22.35 & $\alpha$-Terpinyl acetate & $>95$ & $<5$ & $>95$ & $<5$ & ND & ND & $>95$ & $<5$ \\
\hline 23.92 & 22.81 & $(E)-\beta$-Caryophyllene & $<5$ & $>95$ & $<5$ & $>95$ & $<5$ & $>95$ & $<5$ & $>95$ \\
\hline
\end{tabular}

\subsection{Antioxidant Capacity}

\subsubsection{ORAC}

The antioxidant activities of the four SIEOs were as follows (Table 4): SIEO-3 ${ }^{\text {ORAC }}>$ SIEO-2 ${ }^{\text {ORAC }}$ $\approx \mathrm{SIEO}-4^{\mathrm{ORAC}}>\mathrm{SIEO}-1^{\mathrm{ORAC}}$. ORAC values were expressed in $\mathrm{mg}$ Trolox equivalents (TE)/g SIEO, using the Trolox Equivalent Antioxidant Capacity (TEAC) units. The two main components, camphor and 1,8-cineole, did not show any ORAC antioxidant activity, so that any antioxidant potential of these SIEOs is due to the minor compounds they contain. SIEO-3 has more $\beta$-caryophyllene than the other SlEOs. This compound is one of the most active as seen by this method (Table 5). Interestingly, SlEO-1 has lower amounts of linalool and linalyl acetate than SIEO-2 and -4 , and these compounds, which showed antioxidant activity in this method, could be responsible for the difference.

\subsection{2. $\mathrm{DPPH}$}

This method showed the following results (mg TE/g SIEO) (Table 4): SIEO-3 $3^{\text {DPPH }}>$ SIEO-4 $4^{\text {DPPH }}$ $\geq$ SIEO-2 ${ }^{\text {DPPH }} \geq$ SIEO- $1^{\text {DPPH }}$. All SIEOs were moderately effective in this method, because only two compounds, $\alpha$-terpinene and $\gamma$-terpinene, showed activity against this radical (Table 5).

\subsubsection{ABTS}

The activity against ABTS radical was as follows (mg TE/g SIEO) (Table 4): SIEO-4 ${ }^{\mathrm{ABTS}} \approx$ SIEO- $3^{\mathrm{ABTS}}>\mathrm{SIEO}-1^{\mathrm{ABTS}} \approx \mathrm{SIEO}-2^{\mathrm{ABTS}} \cdot \alpha$-Terpinene and $\gamma$-terpinene are the most active compounds tested in this assay (Table 5).

\subsubsection{Reducing Power (RdP)}

This method showed the following results expressed in mg ascorbic acid equivalents (AAE) $/ \mathrm{kg}$ SIEO (Table 4): SIEO- $3^{\text {RdP }}>$ SIEO-2 ${ }^{\text {RdP }}>$ SIEO- $1^{\text {RdP }}>$ SIEO $-4^{\text {RdP }}$. SIEO-3 showed the highest amount of camphene and SIEO- 4 has slightly less amount of $\alpha$-terpinene and $\gamma$-terpinene.

\subsubsection{Chelating Power (ChP)}

The result from this method was expressed in mg ethylenediaminetetraacetic acid equivalents (EDTAE)/g SIEO (Table 4): SlEO-1 ${ }^{\mathrm{ChP}}>$ SIEO-4 $4^{\mathrm{ChP}} \geq$ SlEO-3 ${ }^{\mathrm{ChP}} \geq \mathrm{SlEO}-2^{\mathrm{ChP}}$. The highest activities of individual compounds to chelate $\mathrm{Fe}^{2+}$ ion were showed by linalool $>\alpha$-terpinene $>$ linalyl acetate $>$ p-cymene (Table 5). 
Table 4. Antioxidant capacity of SIEOs.

\begin{tabular}{cccccc}
\hline \multirow{2}{*}{ SIEO } & ORAC & DPPH & ABTS & RdP & ChP \\
\cline { 2 - 6 } & (mg TE/g SlEO) & (mg TE/g SlEO) & (mg TE/g SlEO) & (mg AAE/kg SIEO) & (mg EDTAE/g SIEO) \\
\hline SIEO-1 & $101.1 \mathrm{c} \pm 5.3$ & $0.0 \mathrm{c} \pm 0.0$ & $0.3 \mathrm{~b} \pm 0.0$ & $1.2 \mathrm{c} \pm 0.1$ & $3.9 \mathrm{a} \pm 0.2$ \\
SIEO-2 & $136.1 \mathrm{~b} \pm 6.3$ & $0.0 \mathrm{bc} \pm 0.0$ & $0.3 \mathrm{~b} \pm 0.0$ & $1.7 \mathrm{~b} \pm 0.1$ & $2.1 \mathrm{c} \pm 0.1$ \\
SIEO-3 & $207.4 \mathrm{a} \pm 10.0$ & $0.1 \mathrm{a} \pm 0.0$ & $0.4 \mathrm{a} \pm 0.0$ & $1.9 \mathrm{a} \pm 0.0$ & $2.4 \mathrm{bc} \pm 0.1$ \\
SIEO-4 & $125.0 \mathrm{~b} \pm 4.6$ & $0.1 \mathrm{~b} \pm 0.0$ & $0.5 \mathrm{a} \pm 0.0$ & $0.9 \mathrm{~d} \pm 0.0$ & $2.6 \mathrm{~b} \pm 0.1$ \\
\hline
\end{tabular}

Table 5. Antioxidant capacity of SIEO compounds ${ }^{\text {a }}$.

\begin{tabular}{|c|c|c|c|c|c|}
\hline \multirow[b]{2}{*}{ Compound } & ORAC & DPPH & ABTS & RdP & ChP \\
\hline & $\begin{array}{c}(\mu \mathrm{mol} \\
\mathrm{TE} / \mathrm{mmol} \mathrm{X})\end{array}$ & $\begin{array}{c}(\mu \mathrm{mol} \\
\mathrm{TE} / \mathrm{mmol} \mathrm{X})\end{array}$ & $\begin{array}{c}(\mu \mathrm{mol} \\
\mathrm{TE} / \mathrm{mmol} \mathrm{X})\end{array}$ & $\begin{array}{c}(\mu \mathrm{mol} \\
\mathrm{AAE} / \mathrm{mmol} \mathrm{X})\end{array}$ & $\begin{array}{c}(\mu \mathrm{mol} \\
\text { EDTAE } / \mathrm{mmol} \mathrm{X})\end{array}$ \\
\hline$\alpha$-Pinene & $\mathrm{N} / \mathrm{D}$ & $\mathrm{N} / \mathrm{D}$ & $\mathrm{N} / \mathrm{D}$ & $\mathrm{N} / \mathrm{D}$ & $16.6 \pm 1.1$ \\
\hline Camphene & $\mathrm{N} / \mathrm{D}$ & $\mathrm{N} / \mathrm{D}$ & $0.1 \pm 0.0$ & $0.5 \pm 0.0$ & $1.6 \pm 0.1$ \\
\hline$\beta$-Pinene & $26.6 \pm 1.6$ & $\mathrm{~N} / \mathrm{D}$ & $0.1 \pm 0.0$ & $\mathrm{~N} / \mathrm{D}$ & $1.8 \pm 0.1$ \\
\hline Myrcene & $\mathrm{N} / \mathrm{D}$ & $\mathrm{N} / \mathrm{D}$ & $\mathrm{N} / \mathrm{D}$ & $\mathrm{N} / \mathrm{D}$ & $2.5 \pm 0.2$ \\
\hline$\alpha$-Terpinene & $\mathrm{N} / \mathrm{D}$ & $0.3 \pm 0.0$ & $4.0 \pm 0.2$ & $1.9 \pm 0.1$ & $62.2 \pm 4.7$ \\
\hline$p$-Cymene & $\mathrm{N} / \mathrm{D}$ & $\mathrm{N} / \mathrm{D}$ & $0.1 \pm 0.0$ & $\mathrm{~N} / \mathrm{D}$ & $20.1 \pm 1.6$ \\
\hline Limonene & $128.0 \pm 10.8$ & $\mathrm{~N} / \mathrm{D}$ & $0.6 \pm 0.0$ & $\mathrm{~N} / \mathrm{D}$ & $5.9 \pm 0.4$ \\
\hline 1,8-Cineole & $\mathrm{N} / \mathrm{D}$ & $\mathrm{N} / \mathrm{D}$ & $\mathrm{N} / \mathrm{D}$ & $\mathrm{N} / \mathrm{D}$ & $1.1 \pm 0.1$ \\
\hline$\gamma$-Terpinene & $171.4 \pm 10.3$ & $0.3 \pm 0.0$ & $2.5 \pm 0.1$ & $0.3 \pm 0.0$ & $0.3 \pm 0.0$ \\
\hline Sabinene hydrate & $\mathrm{N} / \mathrm{D}$ & $\mathrm{N} / \mathrm{D}$ & $0.5 \pm 0.0$ & $\mathrm{~N} / \mathrm{D}$ & $6.7 \pm 0.6$ \\
\hline Linalool & $341.9 \pm 18.5$ & $\mathrm{~N} / \mathrm{D}$ & $0.1 \pm 0.0$ & $\mathrm{~N} / \mathrm{D}$ & $96.9 \pm 5.8$ \\
\hline Camphor & $\mathrm{N} / \mathrm{D}$ & $\mathrm{N} / \mathrm{D}$ & $\mathrm{N} / \mathrm{D}$ & $\mathrm{N} / \mathrm{D}$ & $\mathrm{N} / \mathrm{D}$ \\
\hline Borneol & $\mathrm{N} / \mathrm{D}$ & $\mathrm{N} / \mathrm{D}$ & $\mathrm{N} / \mathrm{D}$ & $\mathrm{N} / \mathrm{D}$ & $\mathrm{N} / \mathrm{D}$ \\
\hline Terpinen-4-ol & $356.0 \pm 13.6$ & $\mathrm{~N} / \mathrm{D}$ & $0.3 \pm 0.0$ & $\mathrm{~N} / \mathrm{D}$ & $1.7 \pm 0.1$ \\
\hline$\alpha$-Terpineol & $310.0 \pm 16.6$ & $\mathrm{~N} / \mathrm{D}$ & $0.2 \pm 0.0$ & $\mathrm{~N} / \mathrm{D}$ & $4.9 \pm 0.3$ \\
\hline Linalyl acetate & $207.1 \pm 13.2$ & $\mathrm{~N} / \mathrm{D}$ & $0.1 \pm 0.0$ & $\mathrm{~N} / \mathrm{D}$ & $27.4 \pm 2.1$ \\
\hline Bornyl acetate & $\mathrm{N} / \mathrm{D}$ & $\mathrm{N} / \mathrm{D}$ & $\mathrm{N} / \mathrm{D}$ & $\mathrm{N} / \mathrm{D}$ & $\mathrm{N} / \mathrm{D}$ \\
\hline$\beta$-Caryophyllene & $394.7 \pm 14.5$ & $\mathrm{~N} / \mathrm{D}$ & $\mathrm{N} / \mathrm{D}$ & $\mathrm{N} / \mathrm{D}$ & $7.1 \pm 0.5$ \\
\hline
\end{tabular}

${ }^{\mathrm{a}} \mathrm{N} / \mathrm{D}=$ Activity lower than 0.05 units at a maximum assay concentration of $100 \mathrm{mM}$.

\subsection{Inhibitory Activity}

\subsubsection{LOX Inhibition}

The degree of inhibition (DI) of LOX was measured at $150 \mu \mathrm{g} / \mathrm{mL}$ for all SlEOs. The results were the following: SIEO- ${ }^{\mathrm{LOX}}(42.4 \pm 0.7 \%)^{\mathrm{a}}>\mathrm{SIEO}-2^{\mathrm{LOX}}(40.4 \pm 0.8 \%)^{\mathrm{b}}>\mathrm{SIEO}-1^{\mathrm{LOX}}(36.6 \pm 0.5 \%)^{\mathrm{c}}>$ SIEO-3 ${ }^{\mathrm{LOX}}(34.2 \pm 0.7 \%) \mathrm{d}$. In addition, $\mathrm{IC}_{50}^{\mathrm{LOX}}$ of some individual compounds has been measured: Bornyl acetate $(74.5 \pm 2.8 \mu \mathrm{g} / \mathrm{mL})$, limonene $(116.1 \pm 3.3 \mu \mathrm{g} / \mathrm{mL})$, camphor $(417.7 \pm 13.0 \mu \mathrm{g} / \mathrm{mL})$ and linalool $(516.0 \pm 6.8 \mu \mathrm{g} / \mathrm{mL})$. Compounds that could not reach $50 \%$ inhibition are expressed as DI (\%) at $514.2 \mu \mathrm{g} / \mathrm{mL}$ : 1,8 -cineole $(30.9 \pm 1.1 \%)$, terpinen-4-ol $(29.6 \pm 1.0 \%)$ and $\alpha$-terpineol $(17.4 \pm 0.2 \%)$. The IC $\mathrm{LOX}_{50}^{\mathrm{LOX}}$ obtained with NDGA $(102.6 \pm 2.8 \mu \mathrm{g} / \mathrm{mL})$ was similar to previous studies [42].

SIEO-1, -2 and -4 showed high amounts of limonene and linalool. Bornyl acetate and limonene were the most active LOX inhibitors. Previous studies showed the anti-LOX activity of other Salvia species. Higher $\mathrm{IC}_{50}$ was showed by the EO from S. officinalis with a 59\% of 1,8-cineole [43]. However, studies with Salvia species from southern Africa showed lower $\mathrm{IC}_{50}$ values [44,45]. Although those EOs were obtained from Salvia genus, the composition of those EOs is different from that of the EOs analyzed in this study, therefore, the results can be significantly different. Studies carried out with Rosmarinus officinalis EO (high content of 1,8-cineole, camphor, $\alpha$-pinene, borneol and camphene) [46] showed anti-LOX capacity similar to that shown with the EOs of this study. No previous studies have been found that analyze the ability of SIEOs to inhibit LOX. 


\subsubsection{AChE Inhibition}

SlEOs showed the following $\mathrm{IC}_{50}^{\mathrm{AChE}}(\mu \mathrm{g} / \mathrm{mL}): \mathrm{SlEO}-4^{\mathrm{AChE}}(108.0 \pm 4.2)^{\mathrm{b}} \approx \operatorname{SIEO}^{\mathrm{AChE}}(108.9 \pm 3.5)$ $\mathrm{b} \approx \operatorname{SIEO}-2^{\mathrm{AChE}}(119.3 \pm 10.4)^{\mathrm{b}}<\operatorname{SIEO}-3^{\mathrm{AChE}}(142.4 \pm 6.1)^{\mathrm{a}}$. In relation to individual compounds, 1,8-cineole $\left(\mathrm{IC}_{50}^{\mathrm{AChE}}=35.2 \pm 1.5 \mu \mathrm{g} / \mathrm{mL}\right)$, was the most potent $\mathrm{AChE}$ inhibitor. $\alpha$-Pinene also showed anticholinesterase activity $\left(\mathrm{IC}_{50}^{\mathrm{AChE}}=446.1 \pm 7.9 \mu \mathrm{g} / \mathrm{mL}\right.$ ). Camphene and terpinen-4-ol could inhibit the enzyme, but it was not possible to calculate their $\mathrm{IC}_{50}^{\mathrm{AChE}}$ due to their low water solubilities $(15 \%$ inhibition reached at $42.4 \pm 3.7 \mu \mathrm{g} / \mathrm{mL}$ for camphene and at $582.4 \pm 38.1 \mu \mathrm{g} / \mathrm{mL}$ for terpinen-4-ol). Other compounds present in these SIEOs showed no inhibition activity or could not be tested due to their limits of solubility. Galantamine was used as standard inhibitor $\left(\mathrm{IC}_{50}^{\mathrm{AChE}}=0.16 \pm 0.03 \mu \mathrm{g} / \mathrm{mL}\right.$ ).

Previous studies $[8,47,48]$ reported bovine and human erythrocyte anticholinesterase activities of commercial SlEOs and their relevant compounds, with some differences compared with our results concerning Electrophorus electricus acetylcholinesterase, perhaps due to the different enzymes studied. Arruda, et al. [49] reported higher $\mathrm{IC}_{50}$ values of anticholinesterase activity of EOs from Hedychium gardnerianum using acetylcholinestase from E. electricus. However, Bonesi, et al. [50] described similar or lower $\mathrm{IC}_{50}$ values than those reported in this study using the EOs from three Pinus species. These differences are mainly due to different composition of EOs. Generally, EOs showed lower anticholinesterase capacities than galantamine and other alkaloids used in the treatment of Alzheimer's disease, but EOs are highly volatile, allowing their use in aromatherapy, which could reduce the side effects [49].

\subsection{Determination of Minimum Inhibitory Concentration (MIC) and Minimum Bactericidal (MBC) or Fungicidal (MFC) Concentrations}

The SIEOs and most compounds with relative concentrations higher than $0.5 \%$ were tested against P. aeruginosa, E. coli, S. aureus and C. albicans. MIC values for P. aeruginosa (Gram-negative) were higher than $20 \mu \mathrm{L} / \mathrm{mL}$ with all the SlEOs tested (data not shown). The results (Table 6) show that Gram-positive bacteria are more sensitive to the EOs than Gram-negative ones, in agreement with other studies [5]. $\alpha$-Pinene and $p$-cymene were more effective against $E$. coli than $S$. aureus, whereas limonene, linalool, borneol, terpinen-4-ol and $\alpha$-terpineol were more active against the latter. C. albicans was inhibited by $\alpha$-pinene, $p$-cymene, limonene and borneol. The results for all the SIEOs were similar to each other because the concentrations of their active molecules were similar. In the case of SlEO-3 (the most different one), it had a lower amount of limonene and linalool, but higher content of borneol, thus compensating for the overall result. The SIEOs showed bactericidal effects because the MBC/MIC was lower than 4, reflecting other studies in different plant species [36,51]. The MIC and MBC values obtained in this study were higher [38,52,53], similar [19,54,55] or lower [56,57] than those reported in previous studies with EOs from Salvia. The lipophilic character of essential oils allows them to pass through cell membranes and produce the lysis [58]. Although the antimicrobial activity of EOs is weaker than that produced by reference antimicrobials [52], they could contribute to the preservation of cosmetic and food products where EOs are mainly used for their odorant characteristics.

Table 6. Antibacterial and antifungal capacities of SIEOs and main individual compounds.

\begin{tabular}{ccccccc}
\hline \multirow{2}{*}{ SIEO/Compound } & \multicolumn{2}{c}{ Escherichia coli } & \multicolumn{2}{c}{ Staphylococcus aureus } & \multicolumn{2}{c}{ Candida albicans } \\
\cline { 2 - 6 } & $\begin{array}{c}\mathbf{M I C} \\
\mathbf{m g} / \mathbf{m L})\end{array}$ & $\begin{array}{c}\mathbf{M B C} \\
\mathbf{( m g / m L})\end{array}$ & $\begin{array}{c}\text { MIC } \\
(\mathbf{m g} / \mathbf{m L})\end{array}$ & $\begin{array}{c}\text { MBC } \\
(\mathbf{m g} / \mathbf{m L})\end{array}$ & $\begin{array}{c}\text { MIC } \\
(\mathbf{m g} / \mathbf{m L})\end{array}$ & $\begin{array}{c}\text { MFC } \\
(\mathbf{m g} / \mathbf{m L})\end{array}$ \\
\hline SlEO-1 & 9.0 & 9.0 & 4.5 & 4.5 & 2.2 & 4.5 \\
SlEO-2 & 8.9 & 8.9 & 4.5 & 4.5 & 2.2 & 4.5 \\
SlEO-3 & 8.9 & 8.9 & 4.5 & 4.5 & 2.2 & 4.5 \\
SlEO-4 & 8.9 & 8.9 & 4.4 & 4.4 & 2.2 & 4.4 \\
$\alpha$-Pinene & 0.5 & 1.0 & 2.1 & $>2.1$ & 0.5 & 0.5 \\
Camphene & $>2.0$ & $>2.0$ & $>2.0$ & $>2.0$ & $>2.0$ & $>2.0$ \\
Sabinene & $>2.0$ & $>2.0$ & $>2.0$ & $>2.0$ & $>2.0$ & $>2.0$ \\
B-Pinene & $>2.0$ & $>2.0$ & $>2.0$ & $>2.0$ & $>2.0$ & $>2.0$ \\
Myrcene & $>2.1$ & $>2.1$ & $>2.1$ & $>2.1$ & $>2.1$ & $>2.1$ \\
\hline
\end{tabular}


Table 6. Cont

\begin{tabular}{ccccccc}
\hline SIEO/Compound & \multicolumn{2}{c}{ Escherichia coli } & \multicolumn{2}{c}{ Staphylococcus aureus } & \multicolumn{2}{c}{ Candida albicans } \\
\cline { 2 - 7 } & $\begin{array}{c}\mathbf{M I C} \\
(\mathbf{m g} / \mathbf{m L})\end{array}$ & $\begin{array}{c}\mathbf{M B C} \\
\mathbf{( m g / m L})\end{array}$ & $\begin{array}{c}\mathbf{M I C} \\
(\mathbf{m g} / \mathbf{m L})\end{array}$ & $\begin{array}{c}\mathbf{M B C} \\
(\mathbf{m g} / \mathbf{m L})\end{array}$ & $\begin{array}{c}\mathbf{M I C} \\
(\mathbf{m g} / \mathbf{m L})\end{array}$ & $\begin{array}{c}\text { MFC } \\
(\mathbf{m g} / \mathbf{m L})\end{array}$ \\
\hline$p$-Cymene & 1.0 & 2.0 & $>2.0$ & $>2.0$ & 0.5 & 0.5 \\
Limonene & 2.0 & 2.0 & 0.3 & 0.3 & 1.0 & 1.0 \\
1,8-Cineole & $>2.3$ & $>2.3$ & $>2.3$ & $>2.3$ & $>2.3$ & $>2.3$ \\
Linalool & 1.1 & 2.3 & 0.6 & 1.1 & 2.3 & 2.3 \\
Camphor & $>2.3$ & $>2.3$ & $>2.3$ & $>2.3$ & $>2.3$ & $>2.3$ \\
Borneol & 1.1 & 1.1 & 0.3 & 0.3 & 0.6 & 0.6 \\
Terpinen-4-ol & 2.3 & 2.3 & 1.1 & 2.3 & $>2.3$ & $>2.3$ \\
$\alpha$-Terpineol & 2.4 & 2.4 & 0.6 & 1.1 & $>2.4$ & $>2.4$ \\
Linalyl acetate & $>3.0$ & $>3.0$ & 3.0 & $>3.0$ & $>3.0$ & $>3.0$ \\
Bornyl acetate & $>2.9$ & $>2.9$ & 2.9 & $>2.9$ & $>2.9$ & $>2.9$ \\
$\beta$-Caryophyllene & $>3.1$ & $>3.1$ & $>3.1$ & $>3.1$ & $>3.1$ & $>3.1$ \\
$\alpha$-Humulene & $>3.0$ & $>3.0$ & 1.6 & 3.0 & $>3.0$ & $>3.0$ \\
Streptomycin sulfate & $1.0 \times 10^{-3}$ & $1.0 \times 10^{-3}$ & $1.0 \times 10^{-3}$ & $1.0 \times 10^{-3}$ & $\mathrm{NT}$ & $\mathrm{NT}$ \\
Fluconazole & $\mathrm{NT}$ & $\mathrm{NT}$ & $\mathrm{NT}$ & $\mathrm{NT}$ & $4.0 \times 10^{-3}$ & $4.0 \times 10^{-3}$ \\
\hline
\end{tabular}

NT $=$ Not tested.

\section{Materials and Methods}

\subsection{Essential Oils}

SIEOs were obtained from $300 \mathrm{~g}$ of the aerial part of plants grown in the south-east of Spain by means of hydrodistillation for $3 \mathrm{~h}$ in a Clevenger-type apparatus [59], dried over anhydrous sodium sulfate and stored at $4{ }^{\circ} \mathrm{C}$ until use. SIEO- 1 and -4 were obtained from plants grown in the Lower Meso-Mediterranean bioclimatic zone, SlEO-2 from plants grown in the Upper Meso-Mediterranean bioclimatic zone and SIEO-3 from plants grown in the Supra-Mediterranean bioclimatic zone [60]. Plant species were identified in the Plant Biology Department of Murcia University by Dr. Pedro Sanchez-Gomez. The Department of Biochemistry and Molecular Biology-A stores the voucher specimens (BMBA160611, BMBA160612, BMBA160613, BMBA160614 for SIEO-1, -2, -3 and -4, respectively).

\subsection{Reagents and Solvents}

The chemical compounds used for the antioxidant methods, the reagents for LOX and AChE inhibition assays and reference antibacterial and antifungal compounds were purchased from Sigma-Aldrich (Madrid, Spain). All compounds were of analytical grade (purity higher than 95\%). All culture media were acquired from VWR Chemicals (Barcelona, Spain): Mueller-Hinton agar (MHA), Mueller-Hinton broth (MHB), Roswell Park Memorial Institute medium (RPMI-1640), Sabouraud dextrose agar (SDA), tryptic soy broth (TSB) and yeast peptone dextrose (YPD). Solvents of analytic grade and buffers were purchased from Merck (Madrid, Spain). Type I $(18 \mathrm{M} \Omega \cdot \mathrm{cm})$ deionized water (MilliQ-Reference, Millipore, Madrid, Spain) was used in this work.

\subsection{FGC-FID and FGC-MS}

The relative proportions of the SIEO compounds were determined using a GC7890 chromatograph (Agilent, Madrid, Spain) equipped with a FID. The detector temperature was $320^{\circ} \mathrm{C}$. The sandwich injections $(0.2 \mu \mathrm{L}$ air, $0.2 \mu \mathrm{L}$ isooctane, $0.2 \mu \mathrm{L}$ air, $0.3 \mu \mathrm{L}$ sample and $0.2 \mu \mathrm{L}$ air, described from plunger to needle) were made using a MPS-2XT automatic multi-purpose sampler (Gerstel, Sevilla, Spain).

The chromatography was performed in a low bleed capillary fused-silica column, SLB-5ms from Supelco (Madrid, Spain; $15 \mathrm{~m}$ length $\times 0.1 \mathrm{~mm}$ internal diameter $\times 0.1 \mu \mathrm{m}$ film thickness) with hydrogen as carrier gas $(0.8 \mathrm{~mL} / \mathrm{min})$ which generates a head pressure of 46.345 psi. This carrier gas was produced with an electrolytic Parker-Domnik-Hunter (Barcelona, Spain) generator. 
The injection conditions were as follows: septum purge $3 \mathrm{~mL} / \mathrm{min}$, split ratio 100:1 and injector temperature $300^{\circ} \mathrm{C}$. GC oven temperature was kept at $60^{\circ} \mathrm{C}$ and programmed to raise up to $300{ }^{\circ} \mathrm{C}$ as follows: to $92{ }^{\circ} \mathrm{C}$ at a rate $15{ }^{\circ} \mathrm{C} / \mathrm{min}$, to $96^{\circ} \mathrm{C}$ at a rate of $1{ }^{\circ} \mathrm{C} / \mathrm{min}$, to $108^{\circ} \mathrm{C}$ at a rate of $20^{\circ} \mathrm{C} / \mathrm{min}$ and kept constant for $0.5 \mathrm{~min}$, to $120^{\circ} \mathrm{C}$ at a rate of $5{ }^{\circ} \mathrm{C} / \mathrm{min}$, to $160{ }^{\circ} \mathrm{C}$ at a rate of $20{ }^{\circ} \mathrm{C} / \mathrm{min}$, to $170{ }^{\circ} \mathrm{C}$ at a rate of $5{ }^{\circ} \mathrm{C} / \mathrm{min}$ and to $300^{\circ} \mathrm{C}$ at a rate of $30^{\circ} \mathrm{C} / \mathrm{min}$, kept constant at $300^{\circ} \mathrm{C}$ for $0.5 \mathrm{~min}$.

The absolute concentrations were determined using calibration curves of each commercially available component described in the SIEOs (Table S1), using the gas chromatograph previously described, coupled with an Agilent MS5975 mass spectrometer with electronic impact ionization and single quadrupole. MS was adjusted to the following conditions: electron ionization energy $70 \mathrm{eV}$, electron-multiplier voltage 1129 , acquisition mass range $30-300 \mathrm{~m} / z, 21.035 \mathrm{scans} \cdot \mathrm{s}^{-1}$, transfer line temperature $280^{\circ} \mathrm{C}$, ion source temperature $230^{\circ} \mathrm{C}$, MS quadrupole temperature $150^{\circ} \mathrm{C}$.

Compounds were identified by comparison of their retention times and the mass spectra of commercially available pure standards (Figures S2 and S3) and the NIST 08 and Wiley 7 data bases. Several dilutions of SIEOs have been made in 2,2,4-trimethylpentane, to obtain their relative and absolute determinations.

\subsection{EsGC-MS}

A Chiraldex B-DM column (Astec, Madrid, Spain; $30 \mathrm{~m}$ length $\times 0.25 \mathrm{~mm}$ internal diameter $\times 0.12 \mu \mathrm{m}$ film thickness) from Supelco, made of 2,3-di-O-methyl-6-t-butylsilyl $\beta$-cyclodextrin, non-bonded to fused silica column, was installed in the previously described device. The injections were similar to the one previously described but, in this case, $0.5 \mu \mathrm{L}$ of sample was injected. The injector and transfer line temperatures were $200{ }^{\circ} \mathrm{C}$. Hydrogen was used as carrier gas (constant flow of $2.5 \mathrm{~mL} / \mathrm{min}, 8 \mathrm{psi}$ starting column head pressure). The column temperature was programmed to increase from $35^{\circ} \mathrm{C}$ to $170{ }^{\circ} \mathrm{C}$ at a rate of $4{ }^{\circ} \mathrm{C} / \mathrm{min}$.

To identify both enantiomers, the retention times and the mass spectra of commercially available pure standards were compared with those of the SIEO compounds, and confirmed with the NIST and Wiley spectral data bases (Figure S4).

\subsection{Antioxidant Capacity}

Five antioxidant methods were performed with SIEOs and their main individual compounds in triplicate. In the oxygen radical absorbance capacity (ORAC) assay, peroxyl radicals are produced by $2,2^{\prime}$-Azobis(2-methylpropionamidine) dihydrochloride (AAPH), which reacts with fluorescein giving a non-fluorescent compound [61]. The antioxidants are able to scavenge these peroxyl radicals. Trolox was used as the reference antioxidant. The 2,2-diphenyl-1-picrylhydrazyl (DPPH) [62] and 2,2'-azino-bis(3-ethylbenzothiazoline-6-sulphonic acid) (ABTS) [63,64] methods measure the bleaching produced by the reduction of the coloured DPPH and ABTS radicals. Trolox was used as the reference antioxidant. The RdP method measure the ability to reduce ferric ions, according to the method of Oyaizu [65]. Ascorbic acid was the reference antioxidant used in this method. The ChP method measured the ability to chelate $\mathrm{Fe}^{2+}$ ion, following the method of Miguel et al. [66]. EDTA was used as reference antioxidant. The SIEOs were diluted in 100\% ethanol in the DPPH, ABTS, RdP and ChP methods, whereas in the ORAC method, SIEOs were diluted in 15\% ethanol to obtain a final concentration of $5 \%$ ethanol in the reaction medium. All measurements were made at the end-point of the reaction, except in the ORAC method (Figure S5).

\subsection{Inhibition Activity}

A LOX preparation from Glycine max (soybean) was acquired from Sigma-Aldrich. LOX inhibitory activity was determined as previously reported [67], based on the absorption at $234 \mathrm{~nm}$ of the hydroperoxyde conjugated dienes $\left(\varepsilon=25,000 \mathrm{M}^{-1} \mathrm{~cm}^{-1}\right)$, which are generated from the oxidation of linoleic acid in the presence of oxygen and LOX. This assay was carried out on a double beam Lambda 35 spectrophotometer (PerkinElmer, Madrid, Spain) with the UV-Winlab software, at $25^{\circ} \mathrm{C}$. SlEOs 
were diluted in $10 \%$ acetonitrile (supergradient quality, $\mathrm{A}_{210}<0.018$ ) and nordihydroguaiaretic acid (NDGA) was used as standard LOX inhibitor.

AChE VI-S from Electrophorus electricus was purchased from Sigma-Aldrich. AChE inhibitory activity was measured in triplicate using a 96-well microplate reader at $25^{\circ} \mathrm{C}$, according to Ellman's method [68]. This enzyme hydrolyzes acetylthiocholine to acetate and thiocholine, which reacts with 5,5-dithio-bis-(2-nitrobenzoic acid) (DTNB) producing a coloured compound with absorbance at $412 \mathrm{~nm}$. The reaction was measured for $10 \mathrm{~min}$ at $25^{\circ} \mathrm{C}$, using a 96 -well microplate reader. SIEOs were diluted in $15 \%$ ethanol, to obtain a final concentration of $5 \%$ ethanol in the reaction medium. Galantamine hydrobromide was used as reference AChE inhibitor.

The DI in both antienzymatic assays were calculated using Equation (1):

$$
D I(\%)=\frac{v_{0}-v_{i}}{v_{0}} \times 100
$$

where $v_{0}$ and $v_{1}$ are the steady state rates without and with inhibitor, respectively. The inhibitions of LOX were reported as DI at $150 \mu \mathrm{g} / \mathrm{mL}$ of each SIEO. Higher SIEO concentrations could not be assayed due to their solubility limits. However, $\mathrm{AChE}$ inhibition could be expressed as $\mathrm{IC}_{50}$. To calculate the $\mathrm{IC}_{50}$ values, data of DI (\%) of seven different concentrations of each SIEO were plotted and fitted by non-linear regression according to Equation (2) using Sigma Plot software (systatsoftware.com) (Figure S6). The inhibitions of LOX and AChE by individual compounds were reported as $\mathrm{IC}_{50}$ or DI, depending on their inhibition capacities and solubilities.

$$
D I(\%)=\frac{D I_{\max }[I]_{0}}{I C_{50}+[I]_{0}}
$$

\subsection{Antimicrobial Activity}

\subsubsection{Microorganisms and Culture Conditions}

The following test microorganisms used in this work were acquired from Sigma-Aldrich: Pseudomonas aeruginosa ATCC 9027, Escherichia coli ATCC 8739, Staphylococcus aureus ATCC 6538, and Candida albicans ATCC 10231. The stock cultures were preserved in TSB or YPD with $15 \%$ glycerol, for bacteria and yeast cells, respectively, at $-80^{\circ} \mathrm{C}$. Isolated colonies from an 18- to $24-\mathrm{h}$ agar plate were transferred to MHB for bacteria and RPMI-1640 for C. albicans.

\subsubsection{MIC and MBC or MFC}

MIC were determined using the broth microdilution method in 96-well microplates, according to the M07-A10 [69] standard for bacteria and the M27-A3 [70] for Candida. Briefly, two-fold dilutions of a $40 \mu \mathrm{L} / \mathrm{mL}$ SIEOs were prepared to obtain a final concentration range of $0.08-20 \mu \mathrm{L} / \mathrm{mL}$ with $0.5 \%$ Tween ${ }^{\circledR} 80$ and $2.5 \%$ DMSO. The antimicrobial activities of main compounds were also tested in the concentration range of $0.12-15 \mathrm{mM}$ with $0.5 \%$ Tween ${ }^{\circledR} 80$ and $2.5 \%$ DMSO as solvent. The final strain concentration was $5 \times 10^{5} \mathrm{CFU} / \mathrm{mL}$ in MHB for the bacteria and $0.5-2.5 \times 10^{3}$ in RPMI-1640 for the yeast. These plates were incubated for $24 \mathrm{~h}$ for bacteria and $48 \mathrm{~h}$ for Candida, both at $35 \pm 1{ }^{\circ} \mathrm{C}$, under aerobic conditions on a plate shaker at $100 \mathrm{rpm}$. Streptomycin $(0.06-8.00 \mu \mathrm{g} / \mathrm{mL})$ and fluconazole $(0.13-16 \mu \mathrm{g} / \mathrm{mL})$ were used as reference antibacterial and antifungal compound, respectively. The negative and positive controls were made to test that all solutions were sterile and that $0.5 \%$ tween and $2.5 \%$ DMSO, used for emulsifying the SIEOs, did not show any antimicrobial activity. MIC is defined as the lowest concentration of EO or individual compound with no visible growth of microorganisms, at the end of the incubation period. Then, $100 \mu \mathrm{L}$ of each well without growth in the MIC assay were spread on MHA (bacteria) or SDA (yeast) and incubated for $24 \mathrm{~h}$ at $35 \pm 1{ }^{\circ} \mathrm{C}$ to determinate the MBC or MFC. The MBC or MFC was defined as the lowest $\mathrm{EO}$ concentration in which microorganisms failed to grow in broth and on agar. All determinations were carried out in triplicate. 


\subsection{Statistical Analysis}

The statistical analyses of data were made using both univariate and multivariate methods [71] Data were recorded as mean \pm standard deviation of at least triplicate determinations. Data values of 0.0 in the tables means values lower than 0.05 units. Data quality was analyzed by ANOVA, and means were confronted using Tukey's (HSD) test, considering differences to be significant at $p<0.05$, represented by different letters next to numerical values in the text and tables. To determine similarity between SIEOs, PCA and AHC based on Euclidean distance were performed. Statistica software (software.dell.com) was used to conduct all statistical analyses.

\section{Conclusions}

S. lavandulifolia has been widely used for its medicinal and flavoring properties [7]. The composition of its EO can vary depending on several factors [14]. In this study, four SlEOs obtained from plants grown in Murcia were soundly analyzed. They were rich in $\alpha$-pinene, camphene, 1,8-cineole and camphor. Moreover, other compounds were found in significant amounts, such as $\beta$-pinene, sabinene, myrcene, limonene and borneol. PCA and AHC analyses showed that SIEO- 1 , -2 and -4 are very similar, but different from SIEO-3. SIEO-1, -2 and -4 have similar concentrations of linalool (16), cis-sabinol (17), linalyl acetate (25) and sabinyl acetate (28), whereas SIEO-3 has higher concentration of camphor (18), borneol (19), (-)-myrtenol (23), (Z)-citral (24) and others.

The enantiomeric distribution for sabinene hydrate, camphor, bornyl acetate, borneol and $\beta$-caryophyllene were similar in all SIEOs, so they can be used as biomolecular markers for these EOs. The enantiomeric distribution is important to prove the authenticity of EOs.

As regards the antioxidant results, SlEO-3 was the most antioxidant in ORAC, DPPH, ABTS and RdP methods. These differences between methods can be explained by the different antioxidant activities of their individual compounds in each method; for example, linalool has a high $\mathrm{ChP}$, but it is less active than others against ABTS radical.

All the SIEOs showed LOX inhibition at $150 \mu \mathrm{g} / \mathrm{mL}$. Although bornyl acetate and limonene were the most active against LOX, the two main compounds (camphor and 1,8-cineole) were also able to reduce the rate of the LOX reaction. Moreover, SIEOs are effective against AChE activity. 1,8-Cineole, a major compound in these EOs, is able to reach $50 \%$ inhibition at a concentration of $35 \mu \mathrm{g} / \mathrm{mL}$. These SIEOs could be used for memory enhancement due to their anti-AChE activities and their low proportion of $\alpha$-thujone [6,9,33]. In fact, there is negligible quantities of $\alpha$-thujone in SlEOs from Murcia, that prevent their undesirable effects on brain, muscle, kidney and liver cells [58].

The SIEOs of this study also showed antimicrobial activity against E. coli, S. aureus and C. albicans, but not against $P$. aeruginosa, which is a highly resistant Gram-negative bacterium. S. aureus and C. albicans showed greater susceptibility to the SIEOs than E. coli, probably because of some individual components, such as limonene and borneol, which are more effective against these two microorganisms.

The extensive knowledge acquired about the composition and the antioxidant, antienzymatic and antimicrobial activities of these SIEOs is useful for confirming their potential applications in agronomic, food, cosmetic and pharmaceutical industries.

Supplementary Materials: Supplementary materials are available online.

Acknowledgments: This work was partially supported by Spanish organizations: Projects 19545/PI/14 (Fundación Séneca, CARM, Murcia, Spain), UMU-15452 and UMU-17766 (Universidad de Murcia, Murcia, Spain). A.-B.C. has a predoctoral contract from Ministerio de Educación Cultura y Deporte (Spain) [FPU13/04013]. Some results of this manuscript have been reported in the PhD Thesis of one of the coauthors (A.-B.C.)

Author Contributions: A.-B.C. and A.C. performed the experiments, analyzed the data and wrote the paper; R.M.-G. contributed samples/reagents/materials/analysis tools and analyzed the data; V.T. and J.T. conceived and designed the experiments.

Conflicts of Interest: The authors declare no conflict of interest. The founding sponsors had no role in the design of the study; in the collection, analyses, or interpretation of data; in the writing of the manuscript, and in the decision to publish the results. 


\section{References}

1. Herraiz-Penalver, D.; Usano-Alemany, J.; Cuadrado, J.; Jordan, M.J.; Lax, V.; Sotomayor, J.A.; Pala-Paul, J. Essential oil composition of wild populations of Salvia lavandulifolia vahl. from Castilla-La Mancha (Spain). Biochem. Syst. Ecol. 2010, 38, 1224-1230. [CrossRef]

2. Ben Farhat, M.; Jordan, M.J.; Chaouech-Hamada, R.; Landoulsi, A.; Sotomayor, J.A. Variations in essential oil, phenolic compounds, and antioxidant activity of Tunisian cultivated Salvia officinalis L. J. Agric. Food Chem. 2009, 57, 10349-10356. [CrossRef] [PubMed]

3. Panagiotopoulos, E.; Kapetanos, C.; Skapeti, M.; Cholevas, C.; Drossopoulos, J.; Loukas, M.; Kintzios, S.E. The ecophysiology of Salvia: Disorders and adaptation. In Sage. The Genus Salvia; Kintzios, S.E., Ed.; Harwood Academic Publisher: Amsterdam, The Netherlands, 2000; Volume 14, pp. 125-133.

4. Santos-Gomes, P.C.; Fernandes-Ferreira, M. Organ- and season-dependent variation in the essential oil composition of Salvia officinalis L. cultivated at two different sites. J. Agric. Food Chem. 2001, 49, 2908-2916. [CrossRef] [PubMed]

5. Usano-Alemany, J.; Herraiz-Penalver, D.; Cuadrado, J.; Diaz, S.; Santa-Cruz, M.; Pala-Paul, J. Seasonal variation of the essential oils of Salvia lavandulifolia: Antibacterial activity. J. Essent. Oil Bear. Plants 2012, 15, 195-203. [CrossRef]

6. Kennedy, D.O.; Dodd, F.L.; Robertson, B.C.; Okello, E.J.; Reay, J.L.; Scholey, A.B.; Haskell, C.F. Monoterpenoid extract of sage (Salvia lavandulaefolia) with cholinesterase inhibiting properties improves cognitive performance and mood in healthy adults. J. Psychopharmacol. 2011, 25, 1088-1100. [CrossRef] [PubMed]

7. Perry, N.S.L.; Bollen, C.; Perry, E.K.; Ballard, C. Salvia for dementia therapy: Review of pharmacological activity and pilot tolerability clinical trial. Pharmacol. Biochem. Behav. 2003, 75, 651-659. [CrossRef]

8. Savelev, S.; Okello, E.; Perry, N.S.L.; Wilkins, R.M.; Perry, E.K. Synergistic and antagonistic interactions of anticholinesterase terpenoids in Salvia lavandulaefolia essential oil. Pharmacol. Biochem. Behav. 2003, 75, 661-668. [CrossRef]

9. Tildesley, N.T.J.; Kennedy, D.O.; Perry, E.K.; Ballard, C.G.; Savelev, S.; Wesnes, K.A.; Scholey, A.B. Salvia lavandulaefolia (Spanish sage) enhances memory in healthy young volunteers. Pharmacol. Biochem. Behav. 2003, 75, 669-674. [CrossRef]

10. Crespo, M.E.; Jimenez, J.; Navarro, C.; Zarzuelo, A. The essential oil of Salvia lavandulifolia subspecies oxyodon-A study of its vegetative cycle. Planta Med. 1986, 52, 367-369. [CrossRef] [PubMed]

11. Perry, N.S.L.; Houghton, P.J.; Sampson, J.; Theobald, A.E.; Hart, S.; Lis-Balchin, M.; Hoult, J.R.S.; Evans, P.; Jenner, P.; Milligan, S.; et al. In Vitro activity of S. lavandulaefolia (Spanish sage) relevant to treatment of Alzheimer's disease. J. Pharm. Pharmacol. 2001, 53, 1347-1356. [CrossRef] [PubMed]

12. Jirovetz, L.; Buchbauer, G.; Denkova, Z.; Slavchev, A.; Stoyanova, A.; Schmidt, E. Chemical composition, antimicrobial activities and odor descriptions of various Salvia sp. And Thuja sp. essential oils. Nutrition 2006, 30, 152-159.

13. Porres-Martinez, M.; Gonzalez-Burgos, E.; Accame, M.E.C.; Gomez-Serranillos, M.P. Phytochemical composition, antioxidant and cytoprotective activities of essential oil of Salvia lavandulifolia Vahl. Food Res. Int. 2013, 54, 523-531. [CrossRef]

14. Porres-Martinez, M.; Gonzalez-Burgos, E.; Carretero, M.E.; Gomez-Serranillos, M.P. Influence of phenological stage on chemical composition and antioxidant activity of Salvia lavandulifolia Vahl. essential oils. Ind. Crops Prod. 2014, 53, 71-77. [CrossRef]

15. Santana, O.; Cabrera, R.; Gimenez, C.; Gonzalez-Coloma, A.; Sanchez-Vioque, R.; de los Mozos-Pascual, M.; Rodriguez-Conde, M.F.; Laserna-Ruiz, I.; Usano-Alemany, J.; Herraiz, D. Chemical and biological profiles of the essential oils from aromatic plants of agro industrial interest in Castilla-La Mancha (Spain). Grasas Aceites 2012, 63, 214-222. [CrossRef]

16. Usano-Alemany, J.; Pala-Paul, J.; Herraiz-Penalver, D. Temperature stress causes different profiles of volatile compounds in two chemotypes of Salvia lavandulifolia Vahl. Biochem. Syst. Ecol. 2014, 54, 166-171. [CrossRef]

17. Sajewicz, M.; Rzepa, J.; Hajnos, M.; Wojtal, L.; Staszek, D.; Kowalska, T.; Waksmundzka-Hajnos, M. GC-MS study of the performance of different techniques for isolating the volatile fraction from sage (Salvia L.) species, and comparison of seasonal differences in the composition of this fraction. Acta Chromatogr. 2009, 21, 453-471. [CrossRef] 
18. Mossi, A.J.; Cansian, R.L.; Paroul, N.; Toniazzo, G.; Oliveira, J.V.; Pierozan, M.K.; Pauletti, G.; Rota, L.; Santos, A.C.A.; Serafini, L.A. Morphological characterisation and agronomical parameters of different species of Salvia sp. (Lamiaceae). Braz. J. Biol. 2011, 71, 121-129. [CrossRef] [PubMed]

19. Pierozan, M.K.; Pauletti, G.F.; Rota, L.; dos Santos, A.C.A.; Lerin, L.A.; Di Luccio, M.; Mossi, A.J.; Atti-Serafini, L.; Cansian, R.L.; Oliveira, J.V. Chemical characterization and antimicrobial activity of essential oils of Salvia L. species. Ciencia Tecnol. Aliment. 2009, 29, 764-770. [CrossRef]

20. Konig, W.A.; Fricke, C.; Saritas, Y.; Momeni, B.; Hohenfeld, G. Adulteration or natural variability? Enantioselective gas chromatography in purity control of essential oils. HRC-J. High Resolut. Chromatogr. 1997, 20, 55-61. [CrossRef]

21. De Sousa, D.P.; Nobrega, F.F.F.; Santos, C.; de Almeida, R.N. Anticonvulsant activity of the linalool enantiomers and racemate: Investigation of chiral influence. Nat. Prod. Commun. 2010, 5, 1847-1851. [PubMed]

22. Sugawara, Y.; Shigetho, A.; Yoneda, M.; Tuchiya, T.; Matumura, T.; Hirano, M. Relationship between mood change, odour and its physiological effects in humans while inhaling the fragrances of essential oils as well as linalool and its enantiomers. Molecules 2013, 18, 3312-3338. [CrossRef] [PubMed]

23. Aruoma, O.I. Free radicals, oxidative stress, and antioxidants in human health and disease. J. Am. Oil Chem. Soc. 1998, 75, 199-212. [CrossRef]

24. Lu, J.M.; Lin, P.H.; Yao, Q.Z.; Chen, C.Y. Chemical and molecular mechanisms of antioxidants: Experimental approaches and model systems. J. Cell. Mol. Med. 2010, 14, 840-860. [CrossRef] [PubMed]

25. Masaki, H. Role of antioxidants in the skin: Anti-aging effects. J. Dermatol. Sci. 2010, 58, 85-90. [CrossRef] [PubMed]

26. Mates, J.M.; Segura, J.A.; Alonso, F.J.; Marquez, J. Anticancer antioxidant regulatory functions of phytochemicals. Curr. Med. Chem. 2011, 18, 2315-2338. [CrossRef] [PubMed]

27. Porres-Martinez, M.; Gonzalez-Burgos, E.; Carretero, M.E.; Gomez-Serranillos, M.P. Major selected monoterpenes alpha-pinene and 1,8-cineole found in Salvia lavandulifolia (Spanish sage) essential oil as regulators of cellular redox balance. Pharm. Biol. 2015, 53, 921-929. [CrossRef] [PubMed]

28. Schwarz, K.; Bertelsen, G.; Nissen, L.R.; Gardner, P.T.; Heinonen, M.I.; Hopia, A.; Huynh-Ba, T.; Lambelet, P.; McPhail, D.; Skibsted, L.H.; et al. Investigation of plant extracts for the protection of processed foods against lipid oxidation. Comparison of antioxidant assays based on radical scavenging, lipid oxidation and analysis of the principal antioxidant compounds. Eur. Food Res. Technol. 2001, 212, 319-328. [CrossRef]

29. Ben Jemaa, M.; Falleh, H.; Neves, M.A.; Isoda, H.; Nakajima, M.; Ksouri, R. Quality preservation of deliberately contaminated milk using thyme free and nanoemulsified essential oils. Food Chem. 2017, 217, 726-734. [CrossRef] [PubMed]

30. Miguel, M.G. Antioxidant and anti-inflammatory activities of essential oils: A short review. Molecules 2010, 15, 9252-9287. [CrossRef] [PubMed]

31. Newcomer, M.E.; Brash, A.R. The structural basis for specificity in lipoxygenase catalysis. Protein Sci. 2015, 24, 298-309. [CrossRef] [PubMed]

32. Kuhn, H.; Banthiya, S.; van Leyen, K. Mammalian lipoxygenases and their biological relevance. BBA-Mol. Cell Biol. Lipid 2015, 1851, 308-330. [CrossRef] [PubMed]

33. Perry, N.S.L.; Houghton, P.J.; Jenner, P.; Keith, A.; Perry, E.K. Salvia lavandulaefolia essential oil inhibits cholinesterase in vivo. Phytomedicine 2002, 9, 48-51. [CrossRef] [PubMed]

34. Kobayashi, H.; Ohnishi, T.; Nakagawa, R.; Yoshizawa, K. The comparative efficacy and safety of cholinesterase inhibitors in patients with mild-to-moderate Alzheimer's disease: A Bayesian network meta-analysis. Int. J. Geriatr. Psychiatry 2016, 31, 892-904. [CrossRef] [PubMed]

35. Wang, C.H.; Wang, L.S.; Zhu, N. Cholinesterase inhibitors and non-steroidal anti-inflammatory drugs as Alzheimer's disease therapies: An updated umbrella review of systematic reviews and meta-analyses. Eur. Rev. Med. Pharmacol. Sci. 2016, 20, 4801-4817. [PubMed]

36. Adrar, N.; Oukil, N.; Bedjou, F. Antioxidant and antibacterial activities of Thymus numidicus and Salvia officinalis essential oils alone or in combination. Ind. Crops Prod. 2016, 88, 112-119. [CrossRef]

37. Bozin, B.; Mlmica-Dukic, N.; Samojlik, I.; Jovin, E. Antimicrobial and antioxidant properties of rosemary and sage (Rosmarinus officinalis L. and Salvia officinalis L., Lamiaceae) essential oils. J. Agric. Food Chem. 2007, 55, 7879-7885. [CrossRef] [PubMed] 
38. Nikolic, M.; Jovanovic, K.K.; Markovic, T.; Markovic, D.; Gligorijevic, N.; Radulovic, S.; Sokovic, M. Chemical composition, antimicrobial, and cytotoxic properties of five Lamiaceae essential oils. Ind. Crops Prod. 2014, 61, 225-232. [CrossRef]

39. ISO (International Organization for Standardization). Oil of Sage, Spanish (Salvia lavandulifolia Vahl); ISO 3526:2005 (E); International Organization for Standardization: Geneva, Switzerland, 2005.

40. Usano-Alemany, J.; Pala-Paul, J.; Herraiz-Penalver, D. Essential oil yields and qualities of different clonal lines of Salvia lavandulifolia monitored in Spain over four years of cultivation. Ind. Crops Prod. 2016, 80, 251-261. [CrossRef]

41. Rzepa, J.; Wojtal, L.; Staszek, D.; Grygierczyk, G.; Labe, K.; Hajnos, M.; Kowalska, T.; Waksmundzka-Hajnos, M. Fingerprint of selected Salvia species by HS-GC-MS analysis of their volatile fraction. J. Chromatogr. Sci. 2009, 47, 575-580. [CrossRef] [PubMed]

42. Kurihara, H.; Kagawa, Y.; Konno, R.; Kim, S.M.; Takahashi, K. Lipoxygenase inhibitors derived from marine macroalgae. Bioorg. Med. Chem. Lett. 2014, 24, 1383-1385. [CrossRef] [PubMed]

43. Albano, S.M.; Lima, A.S.; Miguel, M.G.; Pedro, L.G.; Barroso, J.G.; Figueiredo, A.C. Antioxidant, anti-5-lipoxygenase and antiacetylcholinesterase activities of essential oils and decoction waters of some aromatic plants. Rec. Nat. Prod. 2012, 6, 35-48.

44. Kamatou, G.P.P.; van Zyl, R.L.; van Vuuren, S.F.; Viljoen, A.M.; Figueiredo, A.C.; Barroso, J.G.; Pedro, L.G.; Tilney, P.M. Chemical composition, leaf trichome types and biological activities of the essential oils of four related Salvia species indigenous to Southern Africa. J. Essent. Oil Res. 2006, 18, 72-79.

45. Kamatou, G.P.P.; Viljoen, A.M.; Gono-Bwalya, A.B.; van Zyl, R.L.; van Vuuren, S.F.; Lourens, A.C.U.; Baser, K.H.C.; Demirci, B.; Lindsey, K.L.; van Staden, J.; et al. The in vitro pharmacological activities and a chemical investigation of three South African Salvia species. J. Ethnopharmacol. 2005, 102, 382-390. [CrossRef] [PubMed]

46. El-Massry, K.F.; Farouk, A.; Abou-Zeid, M. Free radical scavenging activity and lipoxygenase inhibition of rosemary (Rosmarinus officinalis L.) volatile oil. J. Essent. Oil Bear. Plants 2008, 11, 536-543. [CrossRef]

47. Perry, N.S.L.; Houghton, P.J.; Theobald, A.; Jenner, P.; Perry, E.K. In Vitro inhibition of human erythrocyte acetylcholinesterase by Salvia lavandulaefolia essential oil and constituent terpenes. J. Pharm. Pharmacol. 2000, 52, 895-902. [CrossRef] [PubMed]

48. Savelev, S.U.; Okello, E.J.; Perry, E.K. Butyryl- and acetyl-cholinesterase inhibitory activities in essential oils of Salvia species and their constituents. Phytother. Res. 2004, 18, 315-324. [CrossRef] [PubMed]

49. Arruda, M.; Viana, H.; Rainha, N.; Neng, N.R.; Rosa, J.S.; Nogueira, J.M.F.; Barreto, M.D. Anti-acetylcholinesterase and antioxidant activity of essential oils from Hedychium gardnerianum Sheppard ex Ker-Gawl. Molecules 2012, 17, 3082-3092. [CrossRef] [PubMed]

50. Bonesi, M.; Menichini, F.; Tundis, R.; Loizzo, M.R.; Conforti, F.; Passalacqua, N.G.; Statti, G.A.; Menichini, F. Acetylcholinesterase and butyrylcholinesterase inhibitory activity of Pinus species essential oils and their constituents. J. Enzym. Inhib. Med. Chem. 2010, 25, 622-628. [CrossRef] [PubMed]

51. Traoré, Y.; Ouattara, K.; Yéo, D.; Doumbia, I.; Coulibaly, A. Recherche des activités antifongique et antibactérienne des feuilles d'Annona senegalensis pers (Annonaceae). J. Appl. Biosci. 2012, 58, 4234-4242.

52. Toplan, G.G.; Kurkcuoglu, M.; Goger, F.; Iscan, G.; Agalar, H.G.; Mat, A.; Baser, K.H.C.; Koyuncu, M.; Sariyar, G. Composition and biological activities of Salvia veneris Hedge growing in Cyprus. Ind. Crops Prod. 2017, 97, 41-48. [CrossRef]

53. Tan, N.; Yazici-Tutunis, S.; Yesil, Y.; Demirci, B.; Tan, E. Antibacterial activities and composition of the essential oils of Salvia sericeo-tomentosa varieties. Rec. Nat. Prod. 2017, 11, 456-461. [CrossRef]

54. Hammer, K.A.; Carson, C.F.; Riley, T.V. Antimicrobial activity of essential oils and other plant extracts. J. Appl. Microbiol. 1999, 86, 985-990. [CrossRef] [PubMed]

55. Bhat, G.; Rasool, S.; Shakeel, U.R.; Ganaie, M.; Qazi, P.H.; Shawl, A.S. Seasonal variation in chemical composition, antibacterial and antioxidant activities of the essential oil of leaves of Salvia officinalis (sage) from Kashmir, India. J. Essent. Oil Bear. Plants 2016, 19, 1129-1140. [CrossRef]

56. Alimpic, A.; Pljevljakusic, D.; Savikin, K.; Knezevic, A.; Curcic, M.; Velickovic, D.; Stevic, T.; Petrovic, G.; Matevski, V.; Vukojevic, J.; et al. Composition and biological effects of Salvia ringens (Lamiaceae) essential oil and extracts. Ind. Crops Prod. 2015, 76, 702-709. [CrossRef] 
57. Somer, N.U.; Sarikaya, B.B.; Erac, B.; Kaynar, E.; Kaya, G.I.; Onur, M.A.; Demirci, B.; Baser, K.H.C. Chemical composition and antimicrobial activity of essential oils from the aerial parts of Salvia pinnata L. Rec. Nat. Prod. 2015, 9, 614-618.

58. Bakkali, F.; Averbeck, S.; Averbeck, D.; Waomar, M. Biological effects of essential oils-A review. Food Chem. Toxicol. 2008, 46, 446-475. [CrossRef] [PubMed]

59. EDQM. European Pharmacopoeia; European Directorate for the Quality of Medicines and HealthCare-Council of Europe: Strasbourg, France, 1997.

60. Rivas-Martínez, S. Nociones sobre fitosociología, biogeografía y bioclimatología en la vegetación de España. (notions about phytosociology, biogeography and bioclimatology in the plants of Spain). In La Vegetación de España; Peinado, M., Rivas-Martinez, S., Eds.; University of Alcalá de Henares: Madrid, Spain, 1987; pp. 17-45.

61. Ou, B.X.; Hampsch-Woodill, M.; Prior, R.L. Development and validation of an improved oxygen radical absorbance capacity assay using fluorescein as the fluorescent probe. J. Agr. Food Chem. 2001, 49, 4619-4626. [CrossRef]

62. Brandwilliams, W.; Cuvelier, M.E.; Berset, C. Use of a free-radical method to evaluate antioxidant activity. Food Sci. Technol. 1995, 28, 25-30. [CrossRef]

63. Khammuang, S.; Sarnthima, R. Laccase from spent mushroom compost of Lentinus polychrous Lev. and its potential for Remazol Brilliant Blue R decolourisation. Biotechnology 2007, 6, 408-413. [CrossRef]

64. Re, R.; Pellegrini, N.; Proteggente, A.; Pannala, A.; Yang, M.; Rice-Evans, C. Antioxidant activity applying an improved ABTS radical cation decolorization assay. Free Radic. Biol. Med. 1999, 26, 1231-1237. [CrossRef]

65. Oyaizu, M. Studies on products of browning reaction. Antioxidative activities of products of browning reaction prepared from glucosamine. Jpn. J. Nutr. 1986, 44, 307-315. [CrossRef]

66. Miguel, M.G.; Cruz, C.; Faleiro, L.; Simoes, M.T.F.; Figueiredo, A.C.; Barroso, J.G.; Pedro, L.G. Foeniculum vulgare essential oils: Chemical composition, antioxidant and antimicrobial activities. Nat. Prod. Commun. 2010, 5, 319-328. [PubMed]

67. Christopher, J.; Pistorius, E.; Axelrod, B. Isolation of an isozyme of soybean lipoxygenase. Biochim. Biophys. Acta 1970, 198, 12-19. [CrossRef]

68. Ellman, G.L.; Courtney, K.D.; Andres, V.; Featherstone, R.M. A new and rapid colorimetric determination of acetylcholinesterase activity. Biochem. Pharmacol. 1961, 7, 88-95. [CrossRef]

69. Clinical and Laboratory Standards Institute (CLSI). Methods for Dilution Antimicrobial Susceptibility Tests for Bacteria That Grow Aerobicaly; Approved Standard-Tenth Edition; Document M07-A10; Clinical and Laboratory Standards Institute: Wayne, PA, USA, 2015.

70. Clinical and Laboratory Standards Institute (CLSI). Reference Method for Broth Dilution Antifungal Susceptibility Testing of Yeast; Approved Standard-Third Edition; Document M27-A3; Clinical and Laboratory Standards Institute: Wayne, PA, USA, 2008.

71. Härdle, W.K.; Simar, L. Applied Multivariate Statistical Analysis, 4th ed.; Springer: Heidelberg, Germany, 2015; p. 580 .

Sample Availability: Samples of the essential oils are available from the authors.

(C) 2017 by the authors. Licensee MDPI, Basel, Switzerland. This article is an open access article distributed under the terms and conditions of the Creative Commons Attribution (CC BY) license (http://creativecommons.org/licenses/by/4.0/). 